\title{
Variations in Heat Flow Across the Goban Spur and Galicia Bank Continental Margins
}

\author{
K. E. LOUDEN
}

Department of Oceanography, Dalhousie University, Halifax, Nova Scotia, Canada

\author{
J.-C. Sibuet, and J.-P. Foucher \\ Ifremer, Centre de Brest, Plouzané, France
}

\begin{abstract}
We present the results of 44 new heat flow stations which were taken in 1984 and 1989 in profiles across the Goban Spur and Galicia Bank continental margins (NW Atlantic Ocean). Simple extensional models indicate that the heat flow across both these Early Cretaceous rifted margins should increase from values of $45-50 \mathrm{~mW} / \mathrm{m}^{2}$ over oceanic crust to $65-80 \mathrm{~mW} / \mathrm{m}^{2}$ on the continents. The rate of this increase should help to constrain the mechanism (simple versus pure shear) by which the upper, more radiogenic continental crust is thinned. Measurements across Goban Spur increase from values of $40-45 \mathrm{~mW} / \mathrm{m}^{2}$ over oceanic crust to $50-55 \mathrm{~mW} / \mathrm{m}^{2}$ near the continental shelf. They follow the predicted trend for pure-shear rifting, but only if the value of upper crustal radiogenic heating is low $\left(1-2 \mu \mathrm{W} / \mathrm{m}^{3}\right)$. Otherwise, they would require the upper crust to thin more rapidly than the total crustal thickness, as with a lower plate, simple-shear margin. Measurements across Galicia Bank show a very different pattern, with similar values over oceanic crust but much lower values $\left(30-35 \mathrm{~mW} / \mathrm{m}^{2}\right)$ nearer land. This is difficult to reconcile with any simple, single rifting event but is more compatible with an origin as a pure-shear or lower plate rather than upper plate margin. We also note that oceanic values of heat flow require asthenospheric temperatures $100^{\circ} \mathrm{C}$ lower than normal for both margins. This indicates that the triple junction in existance between these margin segments during the breakup of Dberia, Europe, and North America was not the site of a major mantle plume.
\end{abstract}

\section{INTRODUCTION}

Two simple models have been commonly presented as prototypes to describe the fundamental extensional characteristics of nonvolcanic continental margins: (1) the pure-shear model [McKenzie, 1978] and its variants and (2) the simple-shear model [Wernicke, 1985]. In pure-shear models, extension is produced by a series of seaward dipping faults in the brittle upper layer and ductal deformation in the lower layer. If the amount of extension differs between these two layers (as discussed by Royden and Keen [1980]), the detachment surface is horizontal. This results in a pattern of crustal and lithospheric thinning that is symmetric for each conjugate margin pair. In the simple-shear model, extension occurs along a single, low-angle detachment fault which penetrates through the crust and possibly into the lithosphere. This nonhorizontal detachment offsets the thinning of the upper region (including the crust) from that of the lower lithospheric region, resulting in an asymmetric conjugate pair of "upper plate" (hanging wall) and "lower plate" (footwall) margins.

Application of these models has been made in a number of detailed case studies in the North Allantic region. Since these margins are known to have formed in the Mesozoic, the initial patterns of lithospheric thinning, which existed at the time of their creation, have been largely destroyed by a long subsequent, period of conductive cooling. Thus observational evidence for characterizing the rifting process largely consists of seismic images of crustal structures from

Copyright 1991 by the American Geophysical Union. reflection and refraction profiles. Of these, the greatest definition has come from multichannel reflection profiles across the sediment-starved margins off western Europe [e.g., Montadert et al, 1979a; Le Pichon and Barbier, 1987; Peddy et al., 1989] or the moderately sedimented margins off eastern Canada [e.g., Keen and de Voogd, 1988; Keen et al., 1989], where a clear image of the faulted, transitional crust has not been obscured by a thick sediment cover.

Other data, such as subsidence histories and thermal anomalies, should also show patterns that are model dependent [Voorhoeve and Houseman, 1988; Buck et al., 1988; Issler et al., 1989]; however, such data have not as yet been very definitive. For example, synrift and postrift subsidence for the pure-shear model should be symmetric on each conjugate margin and directly related to the stretching factor (i.e., areas with large synrift subsidence caused by the thinning of the crust should also be those with large postrift subsidence caused by the cooling of the lithosphere). For a simple-shear margin, the thermal history of the upper plate margin should be dominated by postrift, thermal subsidence; that of the lower plate margin should be dominated by initial, synrift subsidence. Unfortunately, such subsidence histories as determined from borehole samples on sediment-starved margins can suffer large uncertainties in microfaunal estimates of paleobathymetry [e.g., Moullade et al, 1988]. On the other hand, for sediment-filled margins where the shallow paleobathymetry is better controlled, the thick sedimentary layer prevents a. full sampling of syurift sequences, particularly on those sections of highly thinned crust that would best determine characteristic patterns of initial subsidence.

The thermal structure across old margins (i.e. older than a characteristic lithospheric time constant of $50-70$ 
Ma) should also be model specific. While the degree of lithospheric thinning at the time of rifting is no longer well constrained, heat flow measurements should still record the degree of asymmetry in attenuation of the more radiogenic continental crust. In pure-shear extension, we would expect this to be uniformly related to the stretching factor; for simple-shear, we would expect either a more rapid or a more gradual increase, depending on whether the crustal thickening is dominated by the less radiogenic, lower continental crust or more radiogenic, upper continental crust. However, data across old margins, from either boreholes or surface penetrations, suffer from a lack of adequate coverage and only two profiles have been able to be constructed from continent to ocean. One of these profiles, on thick sediments across the Nova Scotian margin off eastern Canada, is disturbed by salt diapirs and made uncertain by poorly constrained borehole conductivities [see Louden and Wright, 1989]. On the other profile across the Biscay margin off western France, Foucher and Sibuet [1980] could show only a very general, qualitative agreement between the pure-shear model and heat flow measurements.

The purpose of this paper is to help supplement these meager data by adding new measurements of surface heat flow across two margins in the northeastern Atlantic. One of these, Goban Spur, shows patterns of crustal thinning that have been associated with a pure-shear process, while the other, Galicia Bank, has different characteristics which have been attributed to either pure-shear or upper plate, simpleshear extension. Based on the previous discussion, we would expect for Goban Spur a uniform increase in heat flow with increasing continental crustal thickness, while for Galicia Bank, the increase should be either similar or more abrupt. Our observations, however, require only a gradual increase across Goban Spur and a decrease across Galicia Bank. This suggests that, in both cases, the radiogenic continental crust thins more rapidly than the total crustal thickness or the original rate of radiogenic heat production was low. The former implies formation by lower plate, simpleshear rifting; the latter by pure-shear rifting. Consistency with observed changes in crustal structure justifies the pure-shear origin for Goban Spur. There is, however, no indication from heat flow measurements for earlier suggestions of a simple-shear, upper plate model for Galicia Bank. Further clarification will require additional data, particularly including measurements of radiogenic heat production from the transitional basement of the Goban Spur and Galicia Bank margins and heat flow observations from their conjugate margins off Newfoundland.

\section{Regional Setting}

The Atlantic margins off western Europe offer an excellent location in which to observe possible variations in heat flow caused by differing processes of crustal thinning. Most importantly, the general tectonics of the region has already been intensively studied and densely sampled with gravity, magnetic, seismic, and borehole data. As previously mentioned, the margins are sediment starved, which means that complications caused by effects of thermal blanketing [Hutchison, 1985; Lucazeau and Le Douaran, 1985] are minimal. Numerous heat flow measurements have also been taken on land [Lucazeau and Vasseur, 1989]. Values of radiogenic heat production in the Paleozoic metamorphosed cratons which border these margins are generally high [e.g., Jolivet et al., 1989], due to the presence of numerous granitic batholiths. Thus the gross difference in heat flow between ocean basin and continent is relatively large, as can readily be seen in Figure 1.

Three margin sections have been particularly well studied: the Celtic margin of the northern Bay of Biscay, the Goban Spur margin southwest of Ireland, and the western Galicia Bank margin off the northwestern Iberian peninsula. On the Celtic margin, a number of heat flow measurements have already been taken [Erickson et al., 1979; Foucher and Sibuet, 1980; Watremez, 1980; J.-P. Foucher, unpublished data, 1988; D. Abbott, personal commun., 1990]. Deep reflection [Montadert et al., 1979a], and refraction profiles [Avedik et al., 1982] define the amount of crustal thinning across the complete continental transition. Recent profiles show evidence for simple shear along a decollement zone that dips toward the continent and cuts across the upper continental crust [Le Pichon and Barbier, 1987]. However, the direction of opening is slightly oblique to the strike of the margin, and the conjugate margin off northern Galicia Bank and the north coast of Spain [Srivastava et al., 1990; Sibuet and Collette, 1991] cannot offer a comparison because it has been affected by subsequent compression during the Eocene Pyrenean orogeny [Le Pichon and Sibuet, 1971]. Therefore, in this study, we will concentrate on the later two margins, Goban Spur and western Galicia Bank, where shallowpenetration heat flow measurements had not previously been taken.

\section{Goban Spur}

The Goban Spur continental margin segment lies to the south of the Porcupine Seabight and to the north of the Jean Charcot escarpment (Figures 1 and 2). It is a relatively wide and shallow margin compared with those margins to the southeast, with an extensive region less than $2000 \mathrm{~m}$ deep (Figure 2). It formed during the Early Cretaceous by separation of the European and North American continents. Immediately to its south, a triple junction was active until chron $33(80 \mathrm{Ma})$, during rotation of the Iberian peninsula to form the Bay of Biscay [Olivet et al., 1984; Srivastava and Tapscott, 1986; Sibuet and Collette, 1991]. The absence of magnetic chron MO in oceanic crust to the west of the margin (Figure 1) [Guennoc et al., 1978; Verhoef et al., 1986] and the dating of the synrift sedimentary sequences on the margin [Montadert et al., 1979a; Roberts et al., 1981; Masson et al., 1985] indicate the beginning of oceanic crustal accretion within late early Albian time (about $105 \mathrm{Ma}$ ).

Reflection profiles across the margin (cf. Figure 13) show a series of rotated fault blocks which probably sole at the lower continental crust [Peddy et al, 1989], in a manner similar to those recognized in the southeast across the Celtic margin [Montadert et al, 1979a]. The tops of these blocks consist of limestones which probably formed in Jurassic shallow seas as part of earlier, aborted phases of rifting. Significant erosion of the upper blocks suggests that they were later uplifted as they were tilted. Within the halfgrabens bounded by the rotated blocks, symrift sequences that were deposited as the margin subsided date from the Early Cretaceous to lower Albian.

Using the method of Withjack and Jamison [1986], Sibuet [1987] has shown from the orientation of basement faults 


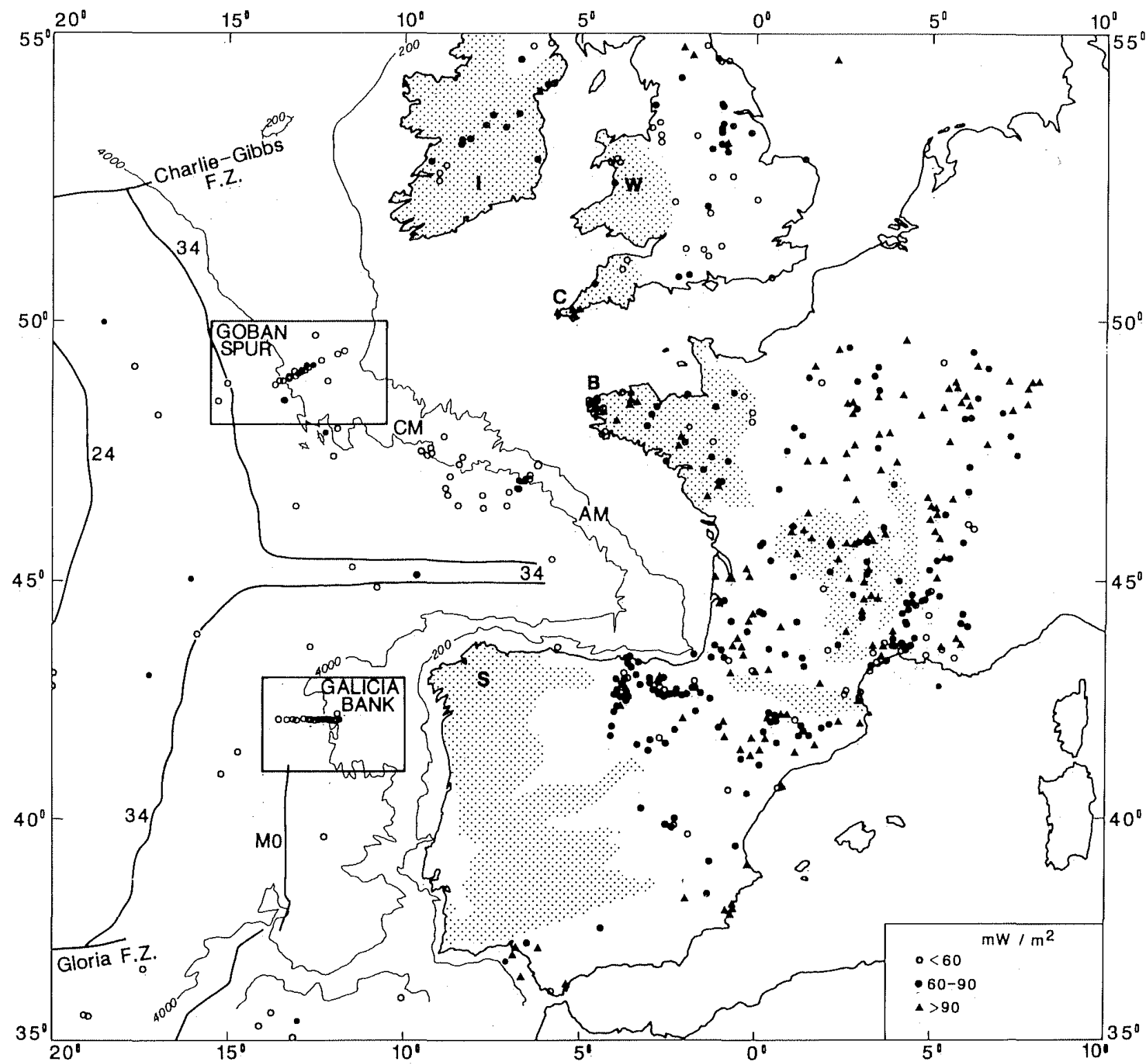

Fig. 1. Generalized, uncorrected heat flow values from the northwestern Atlantic Ocean and adjacent regions of western Europe. Sources of data are: seafloor heat flow [Louden and Wright, 1989; Foucher et al, 1985; Watremez, 1980; Foucher, unpublished data, 1988; D. Abbott, personal communication, 1990]; Spain [Albert-Beltran, 1979]; France [Lucazea u and Vasseur, 1989]; Great Britain [Bloomer et al, 1979]; and Ireland [Brock, 1989]. Boxes locate regions of Goban Spur (Figure 2) and Galicia Bank (Figure 4) surveys. Abbreviations are CM, Celtic margin; and AM, Armorican margin. Letters and shaded areas denote general regions of Paleozoic basement adjacent to the Mesozoic margins [after Montadert et al., 1979b]. Bathymetry and location of magnetic anomaly chrons M0, 34, and 24 are from Lallemand et al. [1985], Guennoc et al. [1978], and Verhoef et al. [1986].

and the rift axis that this margin segment underwent pure extension. Peddy et al. [1989] have suggested that this extension was produced by a pure-shear mechanism. Their primary evidence is that thinning of the reflective zone within the lower crust on the WAM profile across Goban Spur is observed in the same proportion as the upper crust. Since pure-shear margins should form symmetrically, this conclusion apparently conflicts with the much narrower shape of its conjugate, the northeastern flank of Flemish Cap. However, comparison of deep seismic profiles across these two margins, once they have been placed in a reconstructed position [Srivastava et al, 1988], show overall symmetry between continental crustal blocks about a zone of thinned crust, $65 \mathrm{~km}$ wide [Keen et al., 1989]. It was therefore the location of breakup, offset toward the Flemish Cap side of the rift, that led to the asymmetric shape. The prebreakup symmetry of the Moho is more compatible with thinning by pure-shear as opposed to simple-shear extension. This would also explain the absence in the WAM profile of a major low-angle detachment fault within the thinned continental crust across Goban Spur. [Peddy et al., 1989], in contrast to the Celtic margin where a strong $S$ reflector is observed dipping landward [Le Pichon and Barbier, 1987]. Note, however, that this interpretation is disputed by Tankard and Welsink [1988]. They represent. Goban Spur as the upper plate half of a simple-shear boundary, with Orphan Basin as its lower plate conjugate, using the previous reconstructions of Masson and Miles 


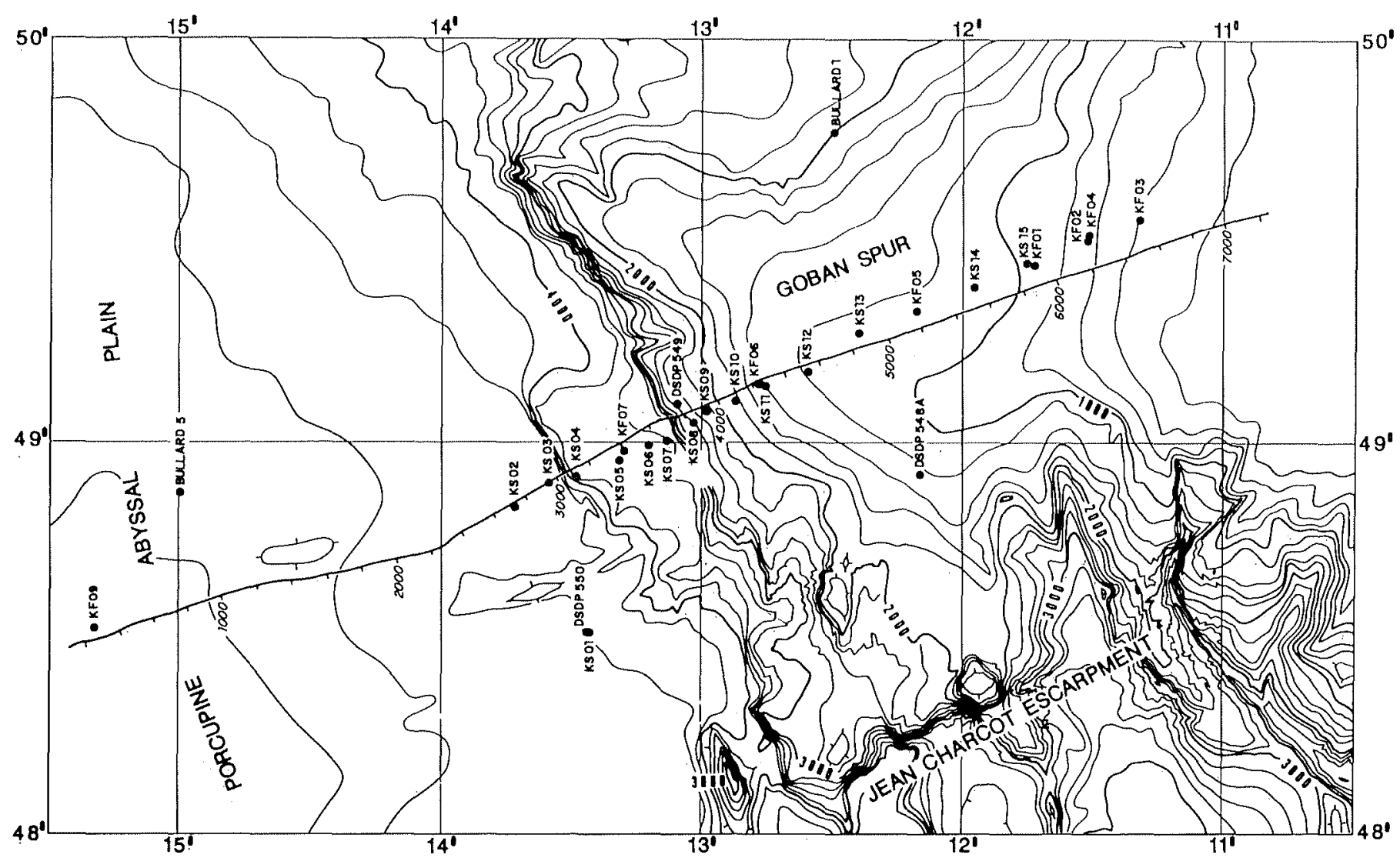

Fig. 2. Bathymetry of Goban Spur margin [Sibuet et al., 1985] with locations of heat flow stations and shot points along the WAM reflection profile [Peddy et al., 1989].

[1984]. No evidence is presented, however, for the existence of the appropriate intracrustal detachment fault.

\section{Galicia Bank}

The West Iberian margin is located to the south of Galicia Bank and northwest of the Vigo and Vasco Da Gama seamounts (Figures 1 and 5 ). Its gross bathymetric structure is quite similar to Goban Spur (cf. Figures 2 and 5), except that it lies approximately $1 \mathrm{~km}$ deeper and is separated from the Portuguese continental mainland to the east by the thickly sedimented Interior basin. The West Iberian margin was created between Iberia and North America to the south of the Biscay triple junction during two phases of rifting [Mauffret and Montadert, 1987]: the first beginning in the Late Jurassic (Oxfordian-Kimmeridgian), during which the Interior basin was formed [Murillas et al., 1990], and the second in the Early Cretaceous (ValanginianHauterivian), during which the final morphology of the margin was acquired. Oceanic crust began to form at the end of this second phase (about $114 \mathrm{Ma}$ ); consistent with the identification of chron M0 (118 Ma) to the south (Figure 1) [Guennoc et al., 1978; Verhoef et al., 1986] and somewhat in advance of accretion westward of Goban Spur as the spreading center propagated to the north.

Reflection profiles across the margin show a series of rotated fault blocks (cf. Figure 13) similar to those observed across Goban Spur and the Celtic margins. Results from ODP Leg 103 drilling [Boillot et al., 1988] show that these blocks were tilted during the later phase of extension (Hauterivian to Aptian), which postdated the subsidence and conformable deposition "of synrift sediments from the previous period of rifting (Late Jurassic to Valanginian). The result was far less surface erosion of the upper parts of the tilted fault blocks than occurred at Goban Spur.

Similar to the Goban Spur margin, the Galicia Bank margin underwent pure extension [Sibuet, 1987]. In this case, however, there is evidence of serpentinized peridotite [Boillot et al., 1980; 1986] near the ocean-continent boundary, which was either emplaced by diapirism through the veil of thinned continental crust [Sibuet et al., 1987] or formed in association with the distal end of a crustal (S?) reflector [Boillot et al., 1987, 1988]. These last authors have suggested that this extension was produced by simple shear along a fault which has cut the entire crust, producing an upper plate margin dominated by upper crustal rocks [Boillot et al., 1986] with low seismic velocity [Sibuet et al., 1987]. This conclusion, however, can be questioned by the fact that the $S$ reflector in this case can only be observed for a very limited extent and, unlike the reflector under the Celtic margin, it dips slightly seaward and thus could not cut through the thickening continental crust. Tankard and Welsink [1988] have proposed an alternate interpretation, which considers Galicia Bank as the lower plate half of a simple shear boundary with the middle Grand Banks as its conjugate upper plate. However, this interpretation also suffers from the lack of clear evidence for a suitable detachment fault, in that no landward dipping intracrustal reflector can be observed under the Grand Bank basins.

\section{Heat Flow Observations}

Marine heat flow observations were taken using a triggerrelease piston corer during two cruises, NORESTLANTE II 
and III: the first to Goban Spur on the N/O Le Suroit in 1984 and the second to Goban Spur and Galicia Bank on the N/O Jean Charcot in 1989. Values of mean conductivity, thermal gradient, and heat flow with their associated standard deviations are reported in Table 1 for all stations, together with water depth, bottom water temperature, geographical position, depth of maximum penetration and correction due to basement topography. We also report data from DSDP sites 548A, 549, and 550 on Goban Spur, which have been recalculated from the original values [Foucher et al., 1985; Hyndman et al., 1987] using a linearly increasing conductivity with depth.

\section{Temperatures}

Sediment temperatures were digitally recorded every 10 $\mathrm{s}$, during single penetrations lasting from 5 to $8 \mathrm{~min}$ of the 4.5- to 9-m-long corer outrigged with a maximum of 7 equally spaced thermistor sensors. Absolute temperatures are calibrated only to within approximately $50 \mathrm{mK}$ accuracy, while relative temperature differences are accurate to $2 \mathrm{mK}$. Bottom water temperatures (BWT) are averages of absolute temperatures, recorded either by all stable thermistors immediately prior to penetration or, in the case of partial penetration, by those thermistors which remained in the water column. The effects of frictional heating upon

TABLE 1. Goban Spur and Galicia Bank Heat Flow

\begin{tabular}{|c|c|c|c|c|c|c|c|c|c|c|c|c|c|c|c|}
\hline Station & $\begin{array}{l}\text { Depth, } \\
\text { m }\end{array}$ & $\begin{array}{l}\mathrm{BMT}, \\
{ }^{\circ} \mathrm{C}\end{array}$ & Latitude, $N$ & Longitude, W & $\begin{array}{c}\mathrm{PEN} \\
\mathbf{m}\end{array}$ & $N_{k}$ & $\mathrm{~W}_{\mathrm{m}^{-1} \mathrm{~K}^{-1}}$ & $\sigma_{k}$ & $N_{G}$ & $\begin{array}{c}G \\
\mathrm{mK} / \mathrm{m}\end{array}$ & $\sigma_{G}$ & $\begin{array}{c}Q \\
\mathrm{~mW} / \mathrm{m}^{2}\end{array}$ & $\sigma_{Q}$ & $\% \mathrm{C}$ & $\begin{array}{c}Q_{c}, \\
\mathrm{~mW} / \mathrm{m}^{2}\end{array}$ \\
\hline N2KS01 & 4400 & 2.66 & $48^{\circ} 30.9^{\prime}$ & $13^{\circ} 26.1^{\prime}$ & 4.5 & 5 & 0.86 & 0.06 & 6 & 46 & 3 & 39.6 & 5.3 & -0.7 & 39.8 \\
\hline N2KSO2 & 4485 & 2.69 & $48^{\circ} 49.9^{\prime}$ & $13^{\circ} 43.1^{\prime}$ & 3.6 & 5 & 0.86 & 0.05 & 6 & 52 & 3 & 44.7 & 5.2 & -0.5 & 44.9 \\
\hline N2KS03 & 4480 & 2.66 & $48^{\circ} 53.5^{\prime}$ & $13^{\circ} 35.5^{\prime}$ & 4.5 & 5 & 0.78 & 0.02 & 6 & 53 & 4 & 41.3 & 4.2 & -8.7 & 45.3 \\
\hline $\mathrm{N}_{2} \mathrm{KSO} 4$ & 3870 & 2.63 & $48^{\circ} 54.5^{\prime}$ & $13^{\circ} 29.0^{\prime}$ & 5.3 & 2 & 0.91 & 0.05 & 7 & 45 & 2 & 41.0 & 4.1 & -4.6 & 42.9 \\
\hline N2KS05 & 3710 & 2.61 & $48^{\circ} 56.9^{\prime}$ & $13^{\circ} 19.1^{\prime}$ & 4.5 & 11 & 0.82 & 0.03 & 6 & 54 & 2 & 44.3 & 3.3 & -2.2 & 45.3 \\
\hline N2KSO6 & 3647 & 2.77 & $48^{\circ} 59.2^{\prime}$ & $13^{\circ} 12.4^{\prime}$ & 9.0 & 26 & 0.84 & 0.05 & 6 & 63 & 2 & 52.9 & 4.8 & -1.7 & 53.8 \\
\hline N2KSO7 & 3520 & 2.82 & $49^{\circ} \quad 0.0^{\prime}$ & $13^{\circ} 8.2^{\prime}$ & 4.8 & 12 & 0.84 & 0.03 & 6 & 53 & 2 & 44.5 & 3.3 & -4.9 & 46.8 \\
\hline N2KSO8 & 2600 & 3.19 & $49^{\circ} \quad 2.6^{\prime}$ & $13^{\circ} 2.3^{\prime}$ & 4.5 & 4 & 0.95 & 0.05 & 6 & 58 & 6 & 55.1 & 8.6 & -6.5 & 58.9 \\
\hline N2KSO9 & 2346 & 3.39 & $49^{\circ} \quad 4.4^{\prime}$ & $12^{\circ} 59.3^{\prime}$ & 4.9 & 7 & 0.93 & 0.09 & 6 & 45 & 3 & 41.9 & 6.8 & -4.4 & 43.8 \\
\hline N2KS10 & 1860 & 3.85 & $49^{\circ} \quad 5.9^{\prime}$ & $12^{\circ} 52.6^{\prime}$ & 4.8 & $*$ & 0.97 & 0.04 & 6 & 66 & 2 & 64.0 & 4.6 & -7.4 & 69.1 \\
\hline N2KS11 & 1445 & 5.44 & $49^{\circ} \quad 8.0^{\prime}$ & $12^{\circ} 45.8^{\prime}$ & 4.9 & * & 0.97 & 0.04 & 4 & 108 & 7 & 104.8 & 11.1 & -3.5 & 108.6 \\
\hline N2KS12 & 1190 & 7.71 & $49^{\circ} 10.3^{\prime}$ & $12^{\circ} 35.7^{\prime}$ & 9.0 & 22 & 1.01 & 0.10 & 6 & 63 & 5 & 63.6 & 11.4 & -3.2 & 65.7 \\
\hline N2KS13 & 950 & 8.10 & $49^{\circ} 16.2^{\prime}$ & $12^{\circ} 24.2^{\prime}$ & 9.0 & 10 & 1.01 & 0.09 & 6 & 55 & 2 & 55.6 & 7.0 & -0.2 & 55.7 \\
\hline N2KS14 & 1125 & 8.27 & $49^{\circ} 23.0^{\prime}$ & $11^{\circ} 57.5^{\prime}$ & 4.9 & 11 & 0.94 & 0.07 & 6 & 50 & 3 & 47.0 & 6.3 & 0.6 & 46.7 \\
\hline N2KS15 & 950 & 8.96 & $49^{\circ} 26.5^{\prime}$ & $11^{\circ} 45.2^{\prime}$ & 4.8 & * & 0.89 & 0.06 & 6 & 57 & 3 & 50.7 & 6.1 & -1.2 & 51.3 \\
\hline N3KF01 & 940 & 9.32 & $49^{\circ} 26.2^{\prime}$ & $11^{\circ} 43.8^{\prime}$ & 6.5 & 39 & 0.89 & 0.06 & & & & & & & \\
\hline N3KF02 & 639 & 10.00 & $49^{\circ} 30.0^{\prime}$ & $11^{\circ} 31.6^{\prime}$ & 5.7 & 15 & 0.90 & 0.05 & & & & & & & \\
\hline N3KF03 & 381 & 10.95 & $49^{\circ} 33.1^{\prime}$ & $11^{\circ} 19.5^{\prime}$ & 3.9 & 15 & 0.90 & 0.02 & 7 & NL & & & & & \\
\hline N3KF04 & 630 & 10.15 & $49^{\circ} 30.5^{\prime}$ & $11^{\circ} 31.4^{\prime}$ & 3.9 & 13 & 0.89 & 0.02 & 7 & NL & & & & & \\
\hline N3KF05 & 1119 & 8.28 & $49^{\circ} 19.3^{\prime}$ & $12^{\circ} 10.8^{\prime}$ & 4.2 & 15 & 0.98 & 0.08 & 5 & $\mathrm{NL}$ & & & & & \\
\hline N3KF06 & 1464 & 5.25 & $49^{\circ} \quad 8.5^{\prime}$ & $12^{\circ} 46.9^{\prime}$ & 3.9 & 14 & 0.97 & 0.07 & 4 & 64 & 6 & 62.1 & 10.3 & -1.6 & 63.1 \\
\hline N3KFo7 & 3672 & 2.51 & $48^{\circ} 58.3^{\prime}$ & $13^{\circ} 18.1^{\prime}$ & 3.9 & $*$ & 0.82 & 0.03 & 7 & 54 & 2 & 44.3 & 3.3 & -3.2 & 45.7 \\
\hline N3KF09 & 4800 & 2.64 & $48^{\circ} 31.5^{\prime}$ & $15^{\circ} 19.6^{\prime}$ & 3.9 & 11 & 0.77 & 0.03 & 6 & 50 & 3 & 38.5 & 3.8 & -5.3 & 40.7 \\
\hline DSDP548A & 1256 & $7.1-7.6$ & $48^{\circ} 55.0^{\prime}$ & $12^{\circ} 9.9^{\prime}$ & 282 & $*$ & $1.40+.0011 \mathrm{~d}$ & & 3 & 35 & 6 & $55.0^{+}$ & 8.0 & 1.4 & $54.2^{+}$ \\
\hline DSDP549 & 2533 & 3.4 & $49^{\circ} \quad 5.3^{\prime}$ & $13^{\circ} 5.9^{\prime}$ & 417 & 24 & $1.38+.0011 \mathrm{~d}$ & & 3 & 24 & 1 & $37.5^{+}$ & 0.4 & -12.9 & $43.1^{+}$ \\
\hline DSDP550 & 4432 & 2.65 & $48^{\circ} 30.9^{\prime}$ & $13^{\circ} 26.4^{\prime}$ & 157 & 25 & $1.30+.0011 \mathrm{~d}$ & & 3 & 44 & 4 & $61.0^{+}$ & 6.0 & -0.7 & $61.4^{+}$ \\
\hline N3KF10 & 5277 & 2.58 & $42^{\circ} 8.5^{\prime}$ & $13^{\circ} 18.7^{\prime}$ & 4.7 & 20 & 0.85 & 0.07 & 5 & 45 & 1 & 8.3 & 4.0 & -3.9 & 39.8 \\
\hline N3KF11 & 5273 & 2.58 & $42^{\circ} 8.7^{\prime}$ & $13^{\circ} 8.7^{\prime}$ & 4.7 & 15 & 0.88 & 0.11 & 7 & 56 & 2 & 49.3 & 7.9 & 2.9 & 47.9 \\
\hline N3KF12 & 5272 & 2.58 & $42^{\circ} 7.7^{\prime}$ & $13^{\circ} 2.1^{\prime}$ & 4.7 & 14 & 0.86 & 0.05 & 6 & 55 & 2 & 47.3 & 4.5 & 2.9 & 46.0 \\
\hline N3KF15 & 5255 & 2.58 & $42^{\circ} 9.7^{\prime}$ & $12^{\circ} 50.2^{\prime}$ & 2.7 & $*$ & 0.88 & 0.10 & 3 & 45 & 2 & 39.6 & 6.3 & -1.8 & 40.3 \\
\hline N3KF16 & 5238 & 2.57 & $42^{\circ} 8.8^{\prime}$ & $12^{\circ} 42.8^{\prime}$ & 3.9 & 28 & 0.94 & 0.11 & 5 & 45 & 2 & 4.3 & 6.8 & 0.2 & 42.2 \\
\hline N3KF 17 & 5233 & 2.57 & $42^{\circ} 8.7^{\prime}$ & $12^{\circ} 37.8^{\prime}$ & 2.0 & 10 & 0.89 & 0.04 & 4 & NL & & & & & \\
\hline N3KF18 & 4990 & 2.55 & $42^{\circ} 8.1^{\prime}$ & $12^{\circ} 31.2^{\prime}$ & 3.9 & 15 & 0.88 & 0.08 & 4 & 48 & 5 & 42.2 & 8.2 & -6.5 & 45.2 \\
\hline N3KF19 & 4865 & 2.53 & $42^{\circ} \quad 8.8^{\prime}$ & $12^{\circ} 24.1^{\prime}$ & 3.9 & * & 0.84 & 0.06 & 5 & 40 & 4 & 33.6 & 5.8 & -7.1 & 36.2 \\
\hline N3KF20 & 4765 & 2.52 & $42^{\circ} \quad 8.9^{\prime}$ & $12^{\circ} 18.0^{\prime}$ & 3.9 & 12 & 0.80 & 0.05 & 6 & 40 & 2 & 32.0 & 3.6 & -8.4 & 34.9 \\
\hline N3KF21 & 4427 & 2.48 & $42^{\circ} \quad 8.7^{\prime}$ & $12^{\circ} 10.2^{\prime}$ & 3.9 & 18 & 0.87 & 0.04 & 4 & 74 & 4 & 64.4 & 6.4 & -11.1 & 72.4 \\
\hline N3KF22 & 4205 & 2.48 & $42^{\circ} \quad 8.9^{\prime}$ & $12^{\circ} 8.2^{\prime}$ & 3.9 & * & 0.86 & 0.03 & 6 & 52 & 2 & 44.7 & 3.3 & -6.3 & 47.7 \\
\hline N3KF23 & 3950 & 2.50 & $42^{\circ} 8.7^{\prime}$ & $12^{\circ} 4.9^{\prime}$ & 3.9 & 5 & 0.86 & 0.03 & 6 & 46 & 2 & 39.6 & 3.1 & 0.4 & 39.4 \\
\hline $\mathrm{N} 3 \mathrm{KF} 24$ & 3482 & 2.55 & $42^{\circ} 7.9^{\prime}$ & $11^{\circ} 58.0^{\prime}$ & 3.9 & 13 & 0.81 & 0.03 & 7 & 32 & 2 & 25.9 & 2.6 & -14.9 & 30.5 \\
\hline N3KF25 & 3570 & 2.47 & $42^{\circ} \quad 8.4^{\prime}$ & $11^{\circ} 55.5^{\prime}$ & 3.9 & $*$ & 0.81 & 0.03 & 7 & 35 & 2 & 28.4 & 2.7 & -11.3 & 32.0 \\
\hline N3KF26 & 2850 & 2.77 & $42^{\circ} \quad 8.4^{\prime}$ & $11^{\circ} 49.1^{\prime}$ & 1.8 & 8 & 1.08 & 0.05 & 4 & NL & & & & & \\
\hline N3KF27 & 2420 & 3.42 & $42^{\circ} \quad 8.2^{\prime}$ & $11^{\circ} 42.2^{\prime}$ & 2.4 & 9 & 0.98 & 0.03 & 5 & NL & & & & & \\
\hline N3Ki28 & 2268 & 3.59 & $42^{\circ} \quad 7.9^{\prime}$ & $11^{\circ} 35.5^{\prime}$ & 3.0 & & & & 7 & $\mathrm{NL}$ & & & & & \\
\hline N3KF29 & 2220 & 3.62 & $42^{\circ} 8.5^{\prime}$ & $11^{\circ} 28.5^{\prime}$ & 3.6 & 15 & 0.93 & 0.07 & 7 & NL & & & & & \\
\hline N3KF30 & 3935 & 2.42 & $12^{\circ} 10.2^{\prime}$ & $12^{\circ} 5.6^{\prime}$ & 3.9 & 13 & 0.80 & 0.05 & 6 & 42 & 3 & 33.6 & 4.5 & -9.5 & 37.1 \\
\hline N3KF31 & 5214 & 2.49 & $42^{\circ} 9.6^{\prime}$ & $12^{\circ} 39.0^{\prime}$ & 3.9 & 26 & 0.93 & 0.08 & 4 & 39 & 9 & 36.3 & 11.5 & -3.4 & 37.5 \\
\hline N3KF32 & 5277 & 2.52 & $12^{\circ} 9.0^{\prime}$ & $13^{\circ} 33.0^{\prime}$ & 3.9 & 15 & 0.81 & 0.04 & 6 & 54 & 3 & 43.7 & 4.6 & 2.0 & 42.9 \\
\hline
\end{tabular}

Depth is water depth; BWT is bottom water temperature; PEN is approximate depth of penetration; $\sigma_{Q}$ is $\sigma_{k} G+\sigma_{G} k$, where $\sigma_{k}$ is standard deviation of thermal conductivity $k$ and $\sigma_{G}$ is standard deviation of temperature gradient $G$; \% $\mathrm{C}$ is topographic correction; $Q$ and $Q_{c}$ are the uncorrected and corrected heat flow. N3KS designates a Norestlante III station; N2KS a Norestlante II station. NL indicates nonlinear temperature gradient.

*Conductivity $k$ assimed from neighboring sites.

+ For DSDP measurements, conductivities are determined assuming a linear increase with depth $d$ (in meters) and heat flow $Q$ is calculated from slope of temperature versus thermal resistance. 
penetration were removed by linear extrapolation of each sensor's sediment temperatures relative to its own BWT as a function of reciprocal time, for postpenetration times exceeding 1-2 min. Values of background temperature calculated from linear fits with poor correlation coefficients (generally resulting in uncertainties in excess of $5 \mathrm{mK}$ ) were discarded.

Goban Spur. Figure 2 shows station locations across Goban Spur and into the Porcupine abyssal plain together with shot points along the WAM reflection profile [Peddy et al., 1989]. Background sediment temperature versus depth relative to the uppermost thermistor penetrating the sediment at each station are plotted in Figure 3 with least squares fits to the mean linear temperature gradient. Some scatter beyond the resolution of the individual temperature determinations exists for several deepwater stations (e.g., N2KS03 and N2KS08). These we assume are due to disturbances during the penetration of the probe.

Other, more systematic departures from linearity are observed in the shallower water stations and are particularly severe for those taken during NORESTLANTE III (e.g.,
N3KF03-05). A plot of sediment temperature versus depth of penetration relative to the average $B W T$ is given in Figure 4 for stations shallower than $1150 \mathrm{~m}$. This suggests that significant variations in bottom water temperature (BTVs) must have occurred immediately prior to the NORESTLANTE III measurements, while BTVs previous to the earlier measurements are negligible. 'The duration and magnitude of the BTVs previons to the NORESTLANTE III observations are approximated using a series of simple step changes (Figure 4 and Table 2). Modeling of the deeper station, N3KF05 (1120 m), using the linear gradient and similar BWT at the neighboring station, N2KS14 (1125 $\mathrm{m}$ ), indicates a period of temperatures elevated by $0.38^{\circ} \mathrm{C}$ from the present value of $8.28^{\circ} \mathrm{C}$, between 5 and 85 days prior to observation in March 1989. Successively smaller increases during roughly the same period are suggested for the shallower stations, N3KF04 $\left(0.28^{\circ} \mathrm{C}\right.$ at $\left.630 \mathrm{~m}\right)$ and $\mathrm{N} 3 \mathrm{KF} 03\left(0.08^{\circ} \mathrm{C}\right.$ at $\left.381 \mathrm{~m}\right)$, assuming that the geothermal gradient remains relatively unchanged. In addition, station N3KF03 requires a temperature decrease of $-0.15^{\circ} \mathrm{C}$ during the period previous to 150 days.
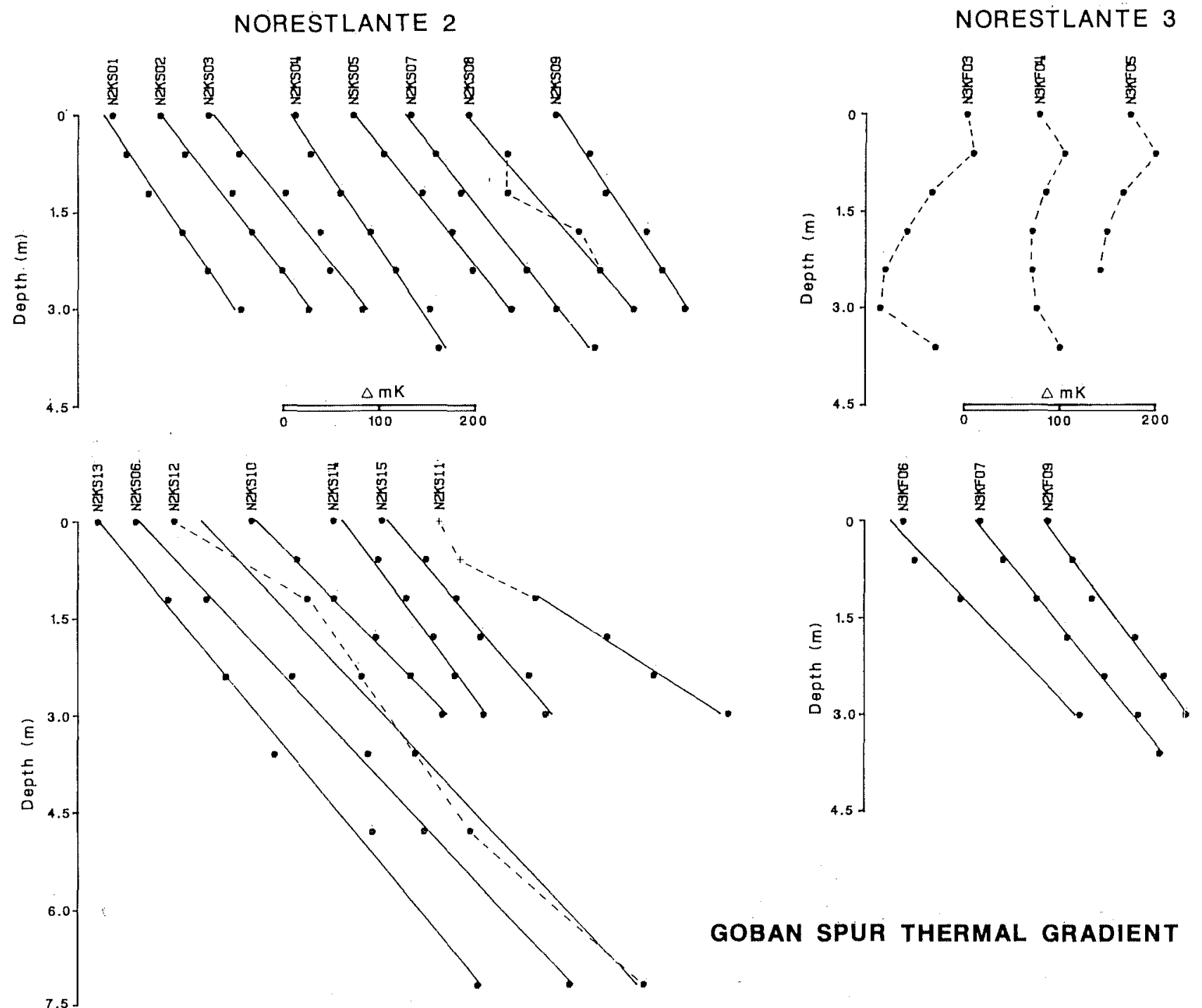

Fig. 3. Sediment temperature versus depth relative to the uppermost thermistor penetrating the sediment at each station on Goban Spur. Solid lines give least squares fits to the linear thermal gradients reported in Table 1 . Large deviations from linearity are shown by dashed lines. Values indicated by crosses are not used in the linear fits. 
The 2-3 month period and increased amplitude toward depths of $1000 \mathrm{~m}$ suggest that these temperature fluctuations are caused by an interaction between shortterm, randomly occurring mesoscale eddies and the long-term northward motion of Mediterranean outflow.
Measurements at $47^{\circ} \mathrm{N}, 14^{\circ} 50^{\prime} \mathrm{W}$ from the Tourbillon experiment, during the period September 1979 to May 1980 [Le Groupe Tourbillon, 1983], show temperature variations from two eddies, each of 2 months duration separated by a 4-month quiet period. Amplitudes increase from $0.4^{\circ} \mathrm{C}$
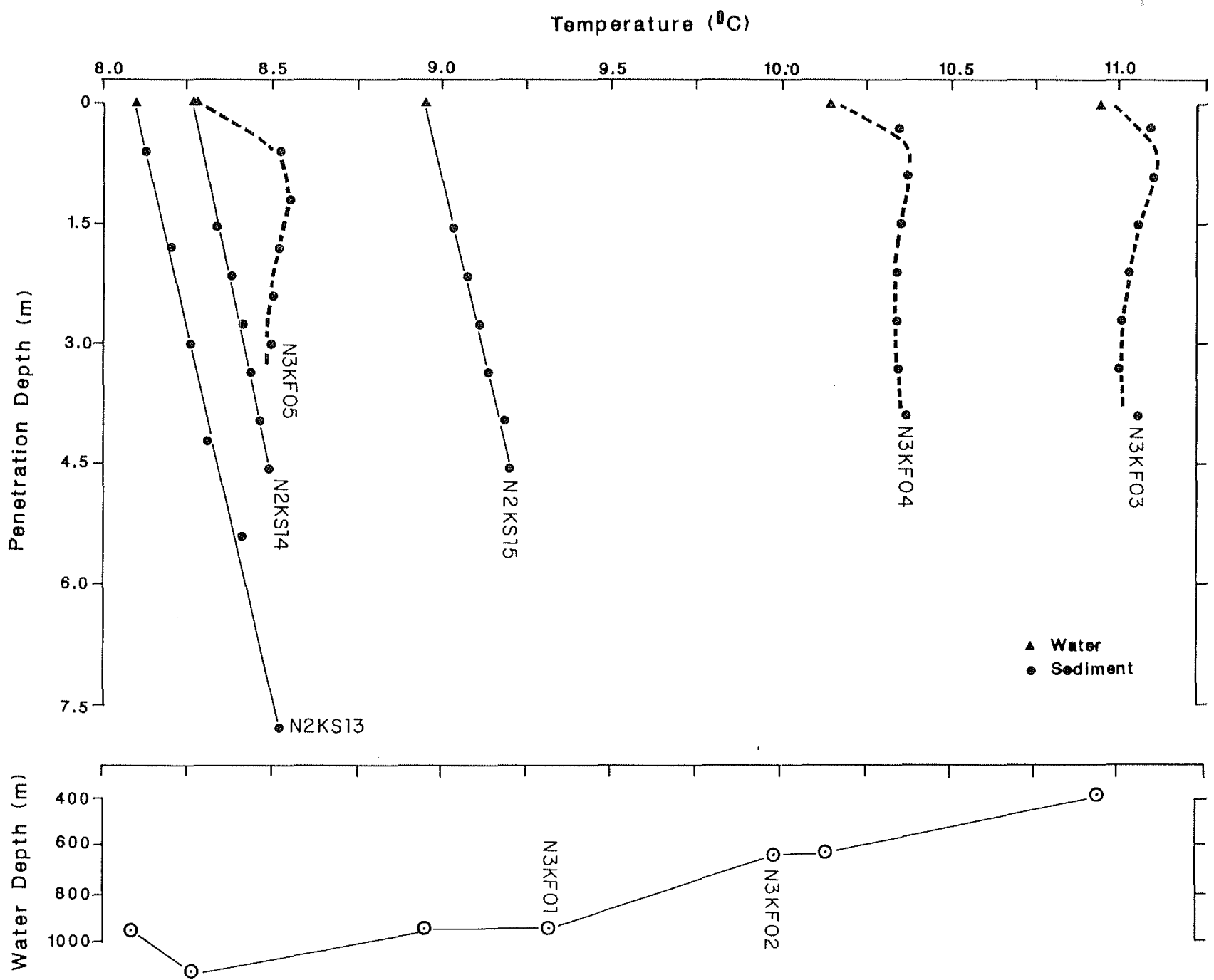

GOBAN SPUR

Fig. 4. Sediment temperature versus depth (solid circles) relative to each station's average bottom water temperature (solid triangles) for Goban Spur stations from the upper margin (water depths less than $1150 \mathrm{~m}$ ). Solid lines show least squares fits to the linear thermal gradients reported in Table 1; dashed lines show non linear fits from themal models with variations in bottom water temperature given in Table 2. Open circles show BWTs versus water depth.

TABLE 2. Square-Wave Models of Bottom Water Temperature Variations

\begin{tabular}{|c|c|c|c|c|c|c|}
\hline Station & $\begin{array}{c}\text { Depth } \\
\text { m }\end{array}$ & $\begin{array}{l}\text { BTV, } \\
{ }^{\circ} \mathrm{C}\end{array}$ & $\begin{array}{c}\text { Period, } \\
\text { days }\end{array}$ & $\begin{array}{c}\text { Grad, } \\
\mathrm{mK} / \mathrm{m}\end{array}$ & $\begin{array}{c}\mathrm{BWT} \\
{ }^{\circ} \mathrm{C}\end{array}$ & $\stackrel{k}{k} \mathrm{~W}^{-1} \mathrm{~K}^{-1}$ \\
\hline & & & Goban Spur & & & \\
\hline N3KF05 & 1119 & +0.38 & $5-85$ & 50 & 8.28 & 0.95 \\
\hline $\mathrm{N} 3 \mathrm{KFO}_{4}$ & 630 & +0.28 & $2-75$ & 53 & 1.0 .15 & 0.90 \\
\hline \multirow[t]{3}{*}{ N3KF03 } & 381 & +0.08 & $2-80$ & 50 & 10.80 & 0.90 \\
\hline & & -0.15 & $>150$ & & & \\
\hline & & & Galicia Bank & & & \\
\hline N3KF28-29 & 2245 & +0.25 & $<80$ & 35 & 3.39 & 0.95 \\
\hline N3KF26 & 2850 & -0.12 & $<30$ & 35 & 2.77 & 1.00 \\
\hline N3KF 25 & 3570 & -0.04 & $<2$ & 35 & 2.47 & 0.80 \\
\hline
\end{tabular}

Period is days before measurement of sediment temperatures; BTV is change in bottom watex temperature relative to BWT; Grad is geothermal gradient; BWT is bottom water temperature; $k$ is thermal conductivity. 
at $400-600 \mathrm{~m}$ to $>1.0^{\circ} \mathrm{C}$ between 850 and $1500 \mathrm{~m}$, and subsequently decrease to $<0.1^{\circ} \mathrm{C}$ for depths greater than $2000 \mathrm{~m}$. The middle region of high temperature variability with time also shows a relatively rapid decrease in water temperature with depth, from $10^{\circ} \mathrm{C}$ at $600 \mathrm{~m}$ to $5^{\circ} \mathrm{C}$ at $1400 \mathrm{~m}$ [this study; Fuglister, 1960]. This zone is thought to be governed by a northward movement of the warm, saline Mediterranean outflow that mixes with the colder, fresher middepth water from the Labrador Sea [Reid, 1978]. Variations in this regional flow created by eddies are thought to produce the large temperature fluctuations centered at $1000 \mathrm{~m}$.

Large, randomly occurring BTVs with typical periods of 30-90 days in water depths between 600 and $1500 \mathrm{~m}$ may explain other nonlinearities in the gradients observed on stations N2KS11-12 and N3KF06. They may also degrade the accuracy of geothermal gradients determined in this range of water depths from linear fits to selected sediment temperatures, particularly if they are limited to the upper $3 \mathrm{~m}$ such as at stations N2KS11 and N3KF06. To measure within $10 \%$ error an assumed geothermal gradient of $50 \mathrm{mK} / \mathrm{m}$ from linear fits to sediment temperatures, given random changes in bottom temperature of $\pm 1^{\circ} \mathrm{C}$ with a period of 90 days, requires penetrations of at least $8-10 \mathrm{~m}$ or a detailed monitoring (or assumed stability) of the BWT for $1-2$ years preceding the measurement. It is possible for geothermal gradients to be determined from shallower sediment temperatures, but this would require at least two coincident observations separated in time by a period less than those of the BTVs themselves [Wang and Beck, 1987].
Otherwise, it is possible to have relatively constant gradients as high as $80-100 \mathrm{mK} / \mathrm{m}$ for measurement depths less than $3 \mathrm{~m}$.

Galicia Bank. Figure 5 shows station locations across the Galicia Bank margin and into the Iberia abyssal plain, together with shot points for the GP101 reflection profile [MaufJret and Montadert, 1987]. Sediment temperature versus depth relative to each station's uppermost thermistor are plotted in Figure 6 with mean linear gradients. Scattered values occasionally exist for individual thermistors, particularly those of the deepest. sensors whose cables may have been disturbed during the penetration of the corer into or through hard substrata.

Other, more systematic departures from linearity are primarily observed in the shallowest stations, N2KF2629. Sediment temperatures relative to the mean BWT are plotted in Figure 7 versus depth of penetration for stations between 3500 and $2200 \mathrm{~m}$. This region shows an increase in bottom water temperature across the slope from values of $2.5^{\circ} \mathrm{C}$ at $3600 \mathrm{~m}$ to $3.6^{\circ} \mathrm{C}$ at $2200 \mathrm{~m}$. These depths are below those influenced by the Mediterranean outflow. The vertical temperature gradient is much smaller than that observed in the shallower water depths near Goban Spur discussed in the preceding section. Thus we would not expect to find large BTVs. Instead, however, simple models of these profiles (Figure 7 and Table 2) suggest that (1) an increase of $0.25^{\circ} \mathrm{C}$ occurred roughly 80 days prior to measurement at the shallowest stations, N3KF28-29 and (2) a decrease of $\leq 0.12^{\circ} \mathrm{C}$ occurred several days to a month before measurement at the deeper stations, N2KF25-26.

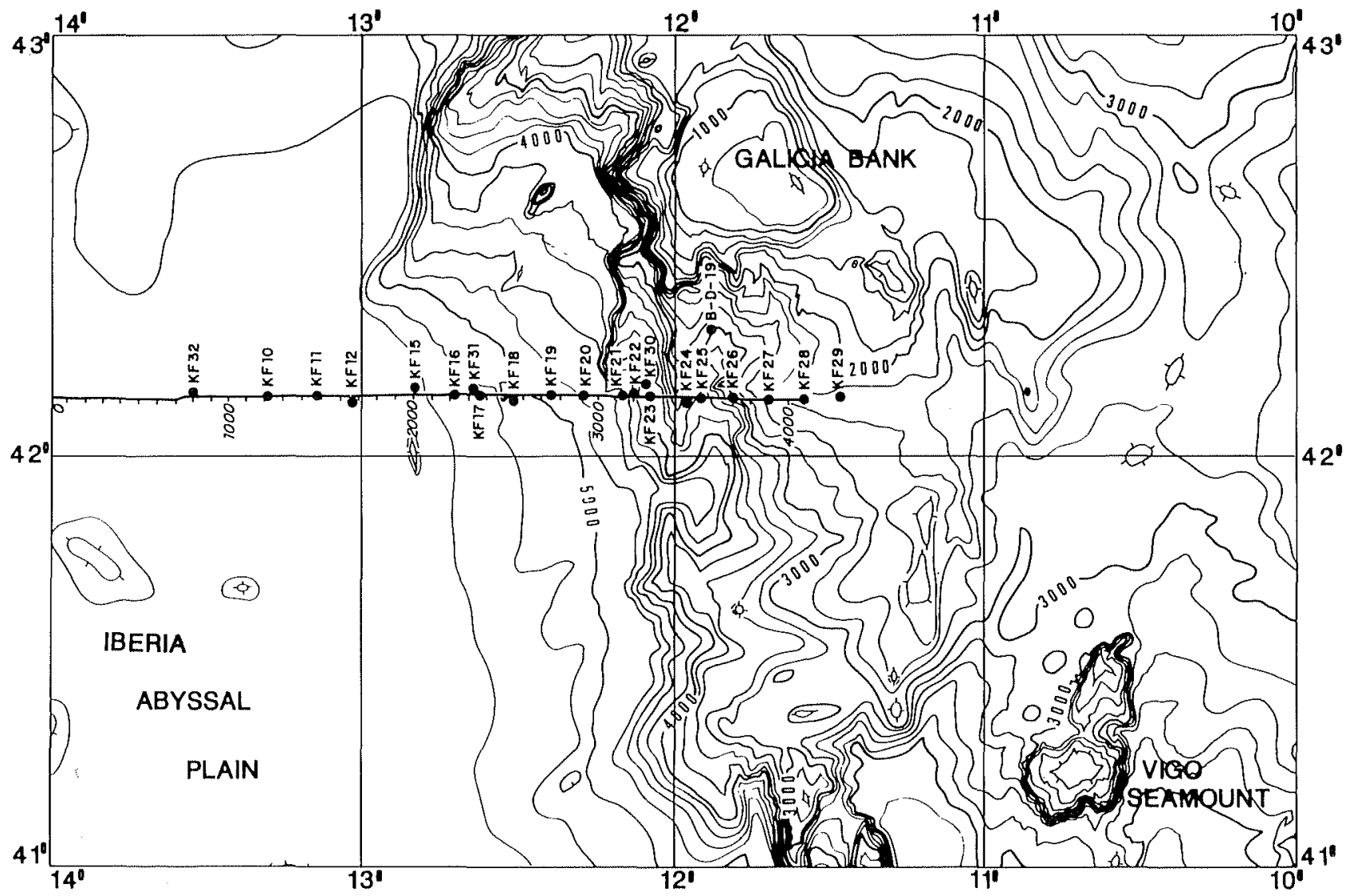

Fig. 5. Bathymetry of Galicia Bank margin [Sibuet et al., 1987] with locations of heat How stations and shot points along the GP-101 reflection profile [Mauffret and Montadert, 1987]. 


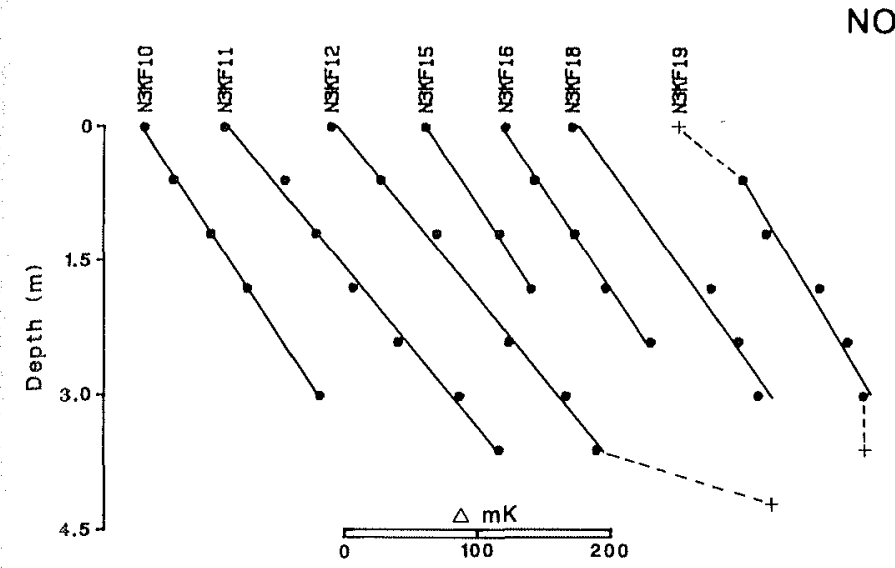

NORESTLANTE 3
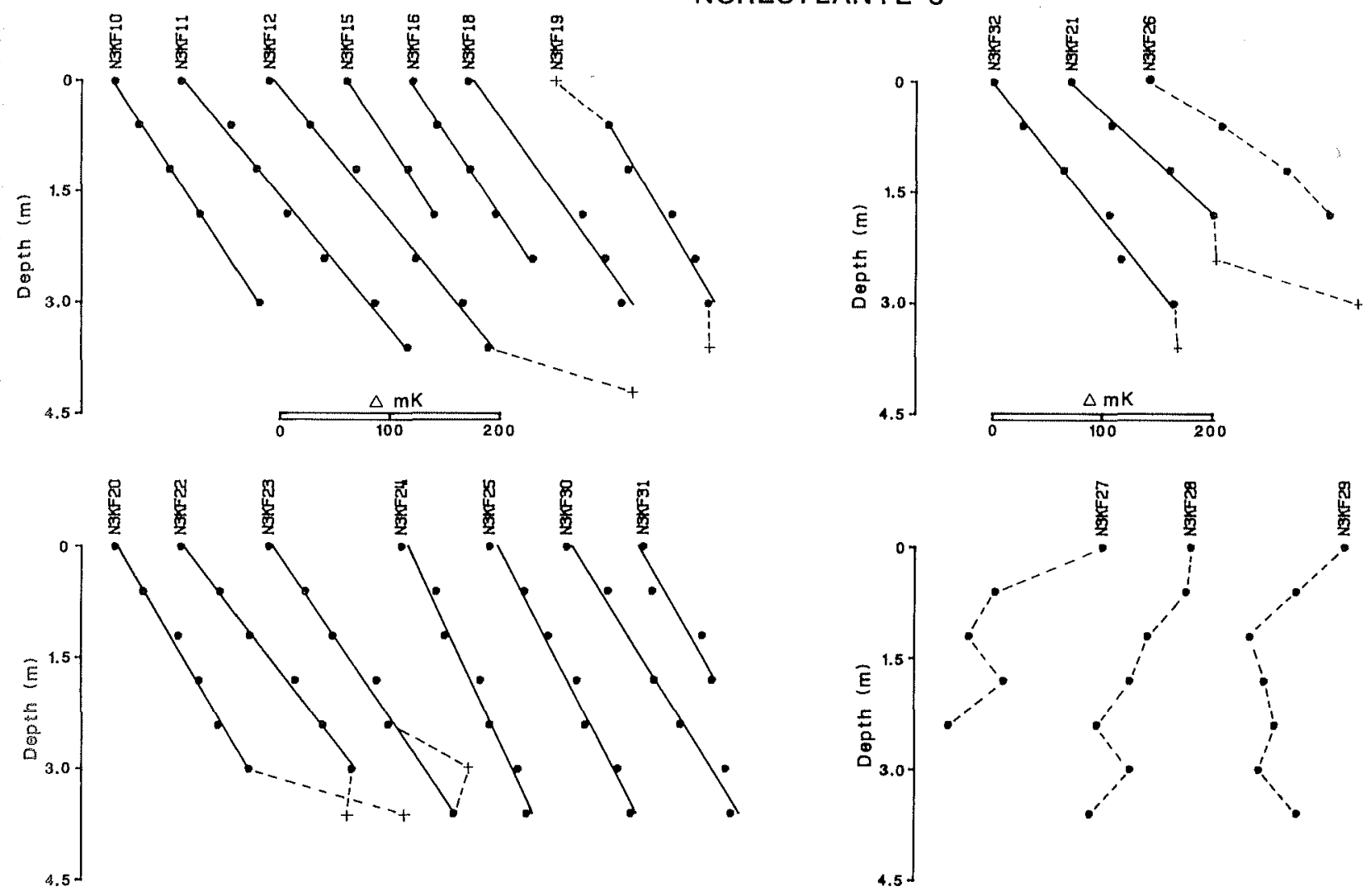

GALICIA BANK THERMAL GRADIENT

Fig. 6. Sediment temperature versus depth relative to the uppermost thermistor penetrating the sediment at each station on Galicia Bank. Other descriptions same as for Figure 3.

An association of these BTVs with mesoscale eddies is suggested by results from NEADS Site 3 at an adjacent westward location in the Iberia abyssal plain $\left(42^{\circ} \mathrm{N}, 14^{\circ} \mathrm{W}\right)$. Water currents exhibit a kinetic energy peak at a typical mesoscale period (100 days) for all depths greater than 3000 $\mathrm{m}$ [Gould, 1983]. The stability of water temperatures, which vary less than $0.1^{\circ} \mathrm{C}$ over depths between 3500 and $5300 \mathrm{~m}$ [this paper; Fuglister, 1960], however, means that significant BTVs caused by these eddy motions are probably limited to water depths less than $3500 \mathrm{~m}$. This is confirmed by the presence of consistent linear gradients determined from stations deeper than $3400 \mathrm{~m}$.

\section{Conductivities}

Thermal conductivities were measured on core sections, immediately after thermal equilibration to shipboard laboratory temperature, using the continuous heating method [Von Herzen and Maxwell, 1959] over periods of 20 to $120 \mathrm{~s}$ with a digitally recording needle probe. Individual measurements using this technique have typical accuracies of $5 \%$ [Goldberg, 1981]. Correction to seafloor temperature and pressure was made using equations from Ralcliffe [1960].

Measurements of thermal conductivity for the Goban Spur sites are plotted in Figure 8. These show generally well defined means $\left(\sigma=0.02-0.10 \mathrm{Wm}^{-1} \mathrm{~K}^{-1}\right)$ with magnitudes ranging from 0.77 to $1.01 \mathrm{Wm}^{-1} \mathrm{~K}^{-1}$ (Table 1 ). The lower of these values come from the abyssal plain and fall within a normal range for oceanic sediments [Louden and Wright, 1989]. In a few cases (i.e., N2KS10, N2KS11,
N2KS15, and N3KF07), we have calculated the heat flow using mean conductivities from adjacent stations which are better sampled. Except for station N3KF01, there is no clear trend of increasing conductivity with sediment depth. Note, however, that there is evidence for increasing conductivity within the greater depth intervals of the DSDP sites. Linear extrapolation of these data yields surface values of conductivity that are higher than those of our cores. This is consistent with conductivities that depend primarily on porosities which decrease in an exponential relationship with depth [Hutchison, 1985].

Conductivity measurements for the Galicia Bank stations are shown in Figure 9. Mean values of 0.80 to 1.08 $W_{m^{-1}} \mathrm{~K}^{-1}$ are only slightly higher than observed along the Goban Spur transect, and standard deviations of 0.03 to $0.11 \mathrm{Wm}^{-1} \mathrm{~K}^{-1}$ are similar. There is little evidence for systematic changes in conductivity with depth apart from the shallow measurements of stations N3KF 18 and N3KF20. There is, however, some evidence for narrow, uncorrelated zones of high conductivity produced from sandy lens, suggestive of turbidite layers. The presence of coarse sediment flows may also explain the occasional difficulty that we experienced in penetrating the sediment at the eastern edge of the abyssal plain.

\section{Heat Flow}

Heat flow values in Table 1 are calculated using the product of the mean gradients and harmonic mean 

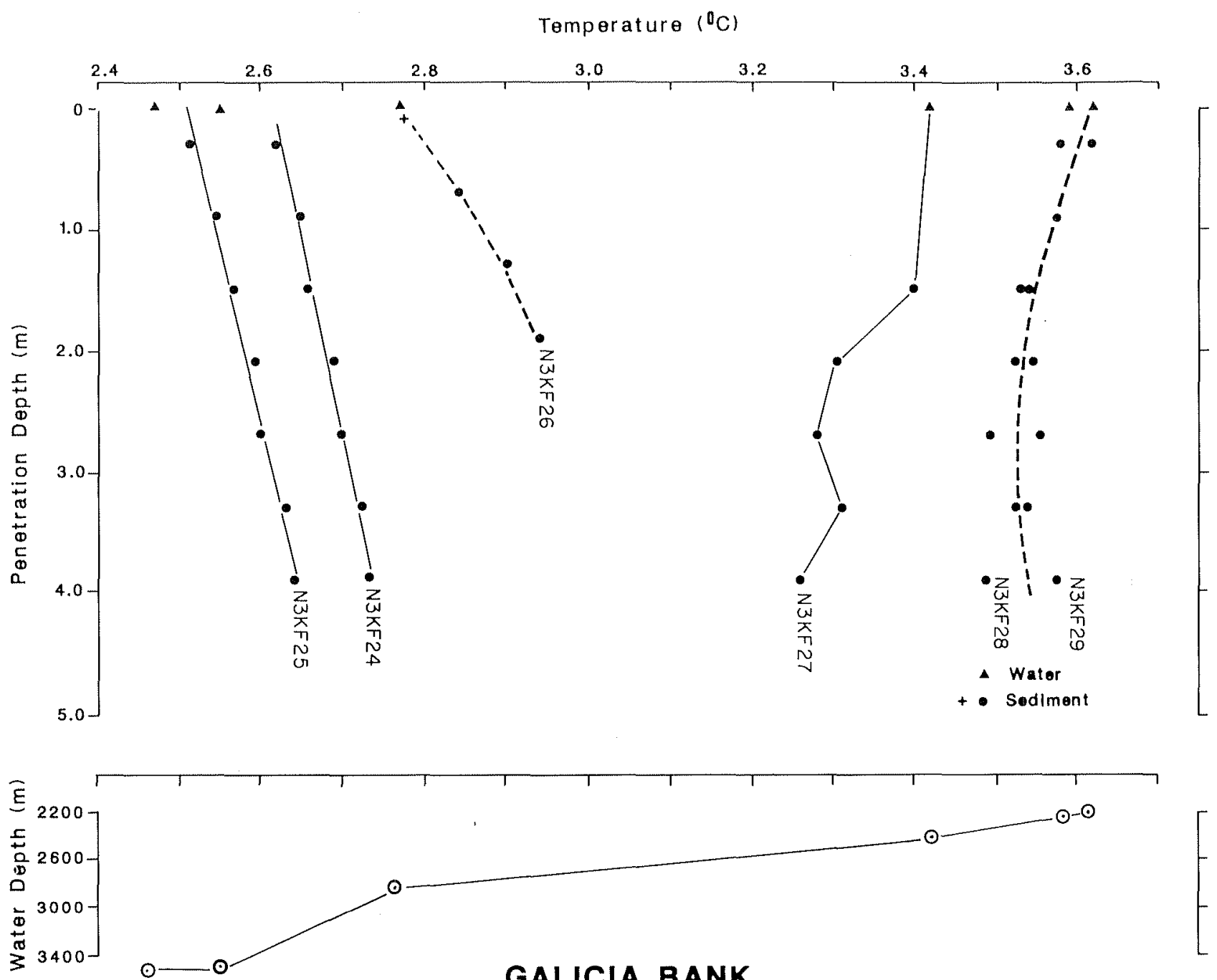

Fig. 7. Sediment temperature versus depth (solid circles) relative to each station's average bottom water temperature (solid triangles) for Galicia Bank stations from the upper margin (water depths less than $3600 \mathrm{~m}$ ). Other descriptions same as for Figure 4 .

conductivities. Standard deviations are calculated in the usual manner from $\sigma_{Q}=G \sigma_{k}+k \sigma_{G}$. Because of limitations in the sampling of the conductivity and temperature values, which differ significantly between stations, calculations of heat flow over smaller intervals are not particularly useful. Most stations, which are not obviously affected by BTVs as discussed above, yield similar values between the averaged and lowermost interval heat flow values. Exceptions are for stations KS10 (see below), KF18, and KF19, for which the heat flows calculated over the lowest interval are reduced by $22-59 \%$.

Topographic corrections are calculated using a twodimensional finite element method (C. Jaupart, personal communication, 1989), to simulate the effects produced by contrasts between the low-conductivity postrift sediment $\left(k=1.0 \mathrm{Wm}^{-1} \mathrm{~K}^{-1}\right)$ and higher-conductivity basement $\left(k=2.5, \mathrm{Wm}^{-1} \mathrm{~K}^{-1}\right)$. Subbottom topography for these layers is constrained by the two multichannel profiles, using assumed sediment and water velocities of 2.0 and $1.5 \mathrm{~km} / \mathrm{s}$, respectively. Corrected heat flow and topographic correction factors across the two margins (Table 1) are shown in Figures 10 and 11 as a function of distance along the reflection profiles. These results show that the topographic correction can be quite large but only very near the westward edges of those fault blocks which lie close to or break the seafloor. This is a region in which observations are rarely, if ever, possible. More typical values from areas of continuous sediment cover are $\pm 10 \%$. They are similar to the results of Foucher and Sibuet [1980] from the comparable environment of the Biscay margin.

Variations in corrected heat flow across the two margins, as observed in Figures 10 and 11, show two rather surprising features:

1. Goban Spur shows the expected increase in heat flow across the margin, from a value of $40 \mathrm{~mW} / \mathrm{m}^{2}$ on the oceanic crust at chron 34 to values of $47-56 \mathrm{~mW} / \mathrm{m}^{2}$ toward the continent at the eastern end of the profile. However, the increase does not start at the ocean continent boundary (OCB), as heat flow values between distances of 150 and $200 \mathrm{~km}$ along profile generally remain stable at $43-45 \mathrm{~mW} / \mathrm{m}^{2}$. DSDP Site 550 shows an isolated high value, which is inconsistent with our geographically coincident measurement at station $\mathrm{N} 2 \mathrm{KS} 01$ as well as with other measurements over the oceanic crust. We have found no explanation for this large discrepancy. A region of high heat flow, with consistent measurements between 59 and 


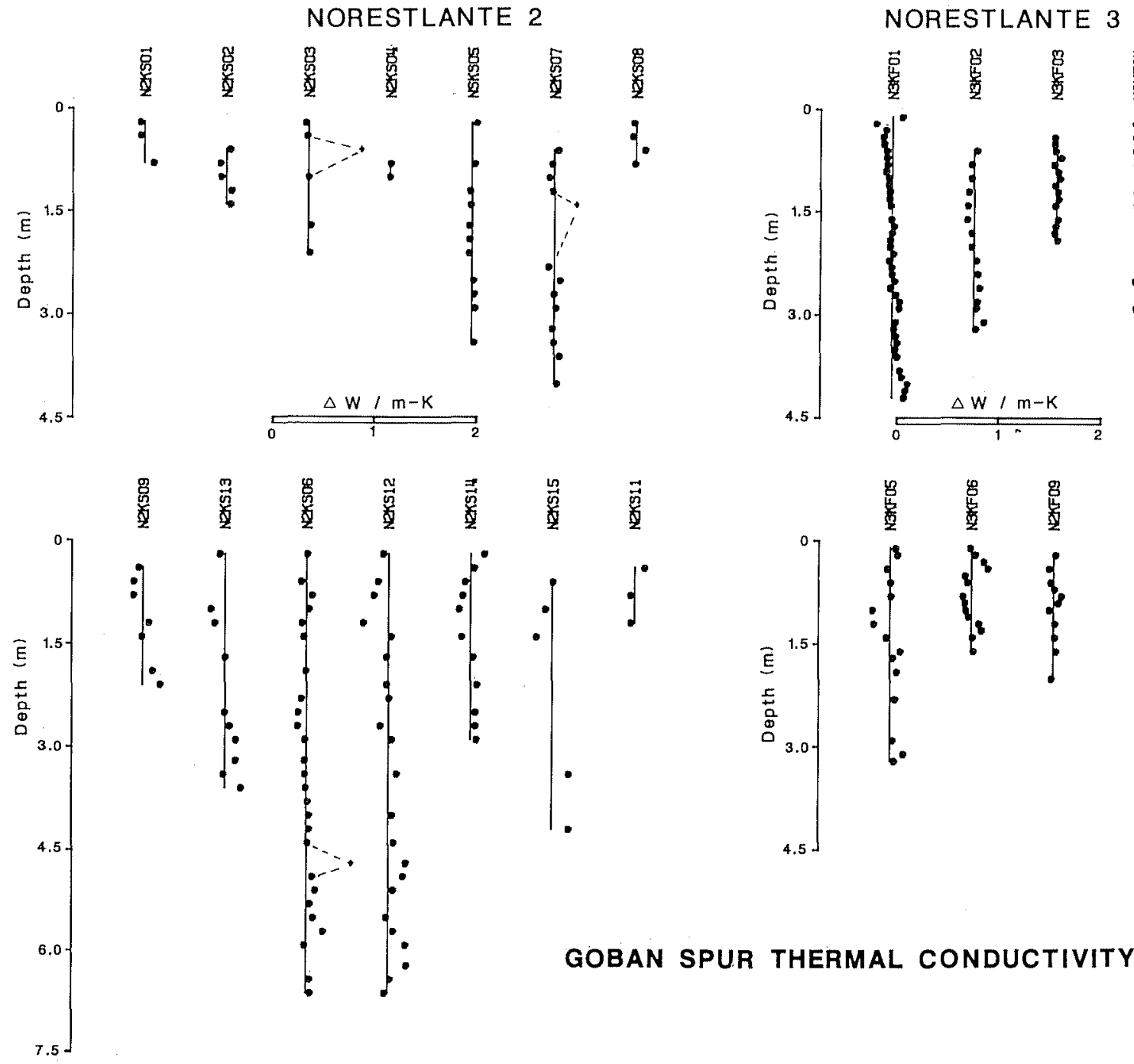

Fig. 8. Thermal conductivity versus sediment penetration depth for piston cores from Goban Spur stations. Values are corrected for water pressure and temperature and are plotted relative to each station's harmonic mean (shown by vertical solid lines). Mean values are calculated from clata given by solid circles and reported in Table 1; dashed lines comect deviant data values (crosses) which are not used.

$69 \mathrm{~mW} / \mathrm{m}^{2}$ from both cruises and one particularly high value of $109 \mathrm{~mW} / \mathrm{m}^{2}$ at station $\mathrm{N} 2 \mathrm{KS} 11$, exists between approximately 200 and $250 \mathrm{~km}$. As discussed before, most of these stations show nonlinearities which may indicate that they have been affected by BTVs. Even the most linear of these stations, N2KS10, exhibits gradients which change from $78 \mathrm{mK} / \mathrm{m}$ for its two uppermost thermistors to 55 $\mathrm{mK} / \mathrm{m}$ between its two lowermost thermistors.

2. For Galicia Bank, there is a slow decrease in heat flow across the margin. Values over the ocean crust, wes! of the presumed $O C B$ at the "lherzolite ridge", lie between 40 and $48 \mathrm{~mW} / \mathrm{m}^{2}$. These are similar to but somewhat less well constrained than oceanic values near Goban Spur. Values from the upper margin generally lie between 31 and $39 \mathrm{~mW} / \mathrm{m}^{2}$, although two values of 45 and $48 \mathrm{~mW} / \mathrm{m}^{2}$ and a single value of $72 \mathrm{~mW} / \mathrm{m}^{2}$ depart from the general trend.

\section{INTERPRETATION}

The surface heat flow data presented in the previous section are most readily interpreted in terms of the pure- shear, depth-independent model of continental extension [McKenzie, 1978]. In this model, heat flow and subsidence are parameterized as a function of a single variable $\beta$, which defines the fractional amount of initial, vertical thinning of both lithosphere and crust. Plotted as a function of $\beta$ rather than distance, the heat flow across both margins can be compared directly even though the profiles across them have significantly different lengths (cf. distance scales in Figures 10 and 11). Following Voorhoeve and Houseman [1988], the effects of radiogenic heat production are included within the model, by addition of the quantity $H h[1-h / 2 L] / \beta$, which linearly reduces as a function of $\beta^{-1}$. Here, $H$ is the rate of radiogenic heating $\left(\mu \mathrm{W} / \mathrm{m}^{3}\right), h$ is the thickness of radiogenic crust (in kilometers), and $L$ is the lithospheric thickness (in kilometers).

Theoretical values of heat flow versus in $\beta$, which result from this model, are shown in Figure 12 for a variety of ages. These show the competition between the increase in heat flow, due to the thinning of the oceanic lithosphere, versus the reduction, due to the thinning of the more radiogenic continental crust. By ages of 105 to $114 \mathrm{Ma}$, 


\section{NORESTLANTE 3}

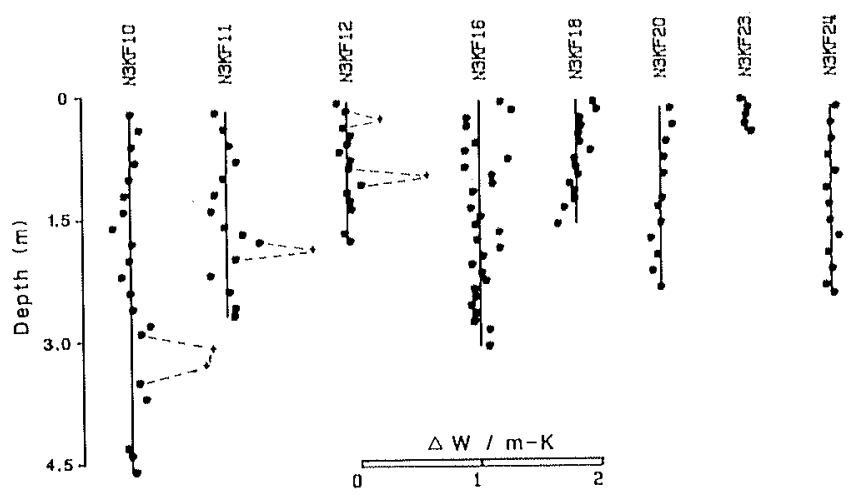

GALICIA BANK THERMAL CONDUCTIVITY

Fig. 9. Thermal conductivity versus sediment penetration depth for piston cores from Galicia Bank stations. Other descriptions same as for Figure 8. representative of the Goban Spur and Galicia Bank margins, respectively, the expected variation in heat flow across the margin is controlled primarily by the crustal contribution. The residual mantle effect of approximately $10 \mathrm{~mW} / \mathrm{m}^{2}$ will not change greatly within the appropriate range of rifting ages for these margins.

Determination of $\beta$ at our station locations must be made using both direct and indirect techniques. For Goban Spur, we use reflection data from the WAM profile [Peddy et al., 1989] as illustrated in Figure $13 a . \quad \beta$ is determined directly, as the ratio of crustal thickness at each station (in seconds of two-way travel time) to crustal thickness over the unstretched continental section at the extreme eastern end of the profile. This assumes that the mean crustal seismic velocity remains the same across the margin and that no lower crust has been added by underplating during the rifting process. This latter assumption has recently been debated by White and Peddy [1990]. However, evidence from seismic velocities [Peddy et al., 1989], basalt composition [Maury et al., 1985], and our oceanic heat flow values (see below) suggests that asthenospheric temperatures were normal (or perhaps below average) during rifting, and therefore melt thicknesses would be less than $1-2 \mathrm{~km}$ for $\beta$ values less than 4 [McKenzie and Bickle, 1988]. Unfortunately, it is not possible to confirm these estimates of $\beta$ from indirect calculation using the geometry of the tilted fault blocks [Le Pichon and Sibuet, 1981], as erosion of the surface blocks is clearly present (Figure 13a). Similar complications for the Biscay margin have led to discrepancies between separate calculations of

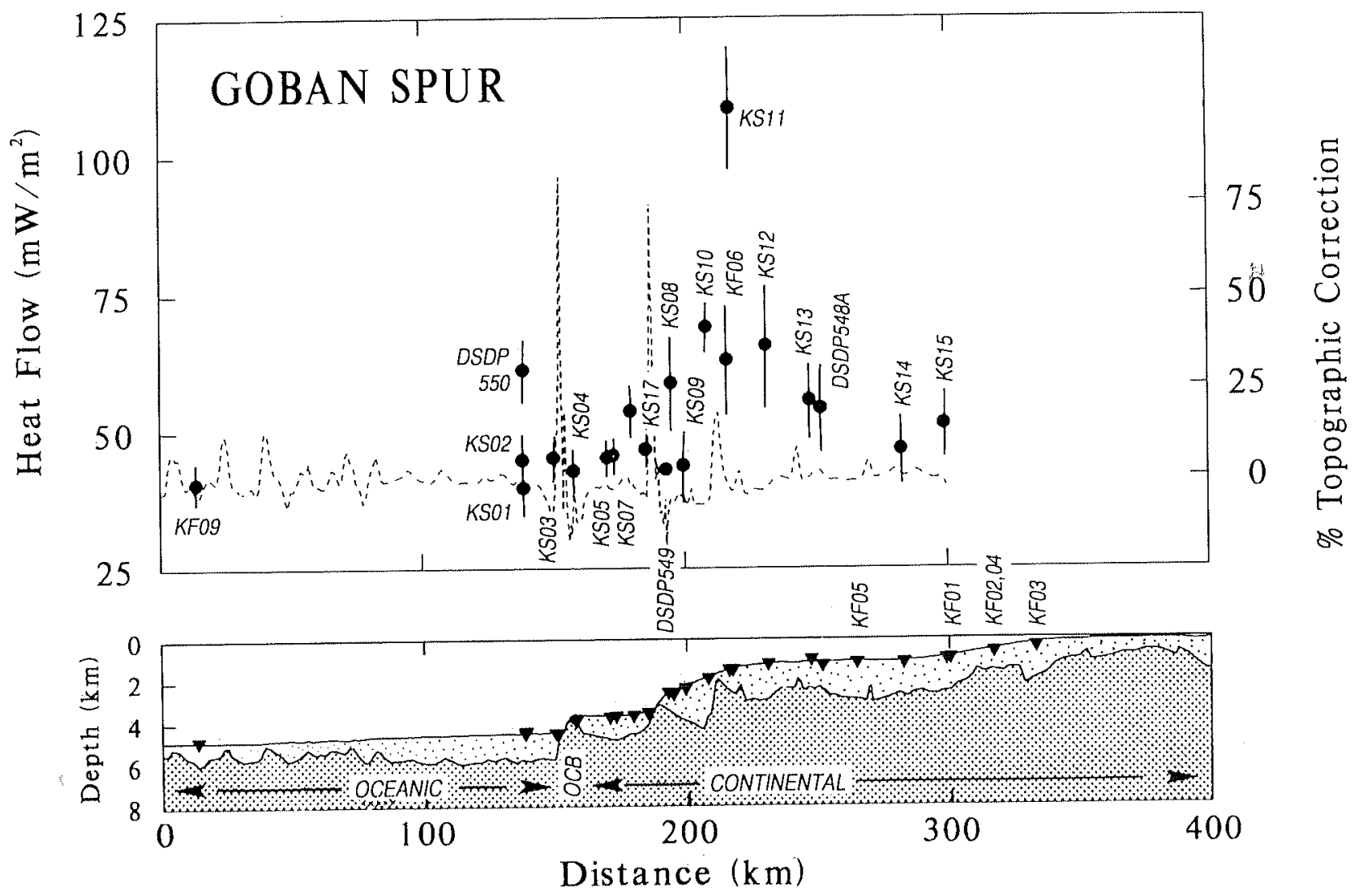

Fig. 10. Station locations, corrected heat flow $( \pm 1 \sigma)$, and topographic correction factor along the WAM reflect. profile. Corrections are calculated for simplified boundaries separating low-conductivity postrift sediments froin high-conductivity basement as identified in the simplified reflection section. Note increase from oceanic to continental values. High values between 200 and $250 \mathrm{~km}$ may be affected by large BTVs. 

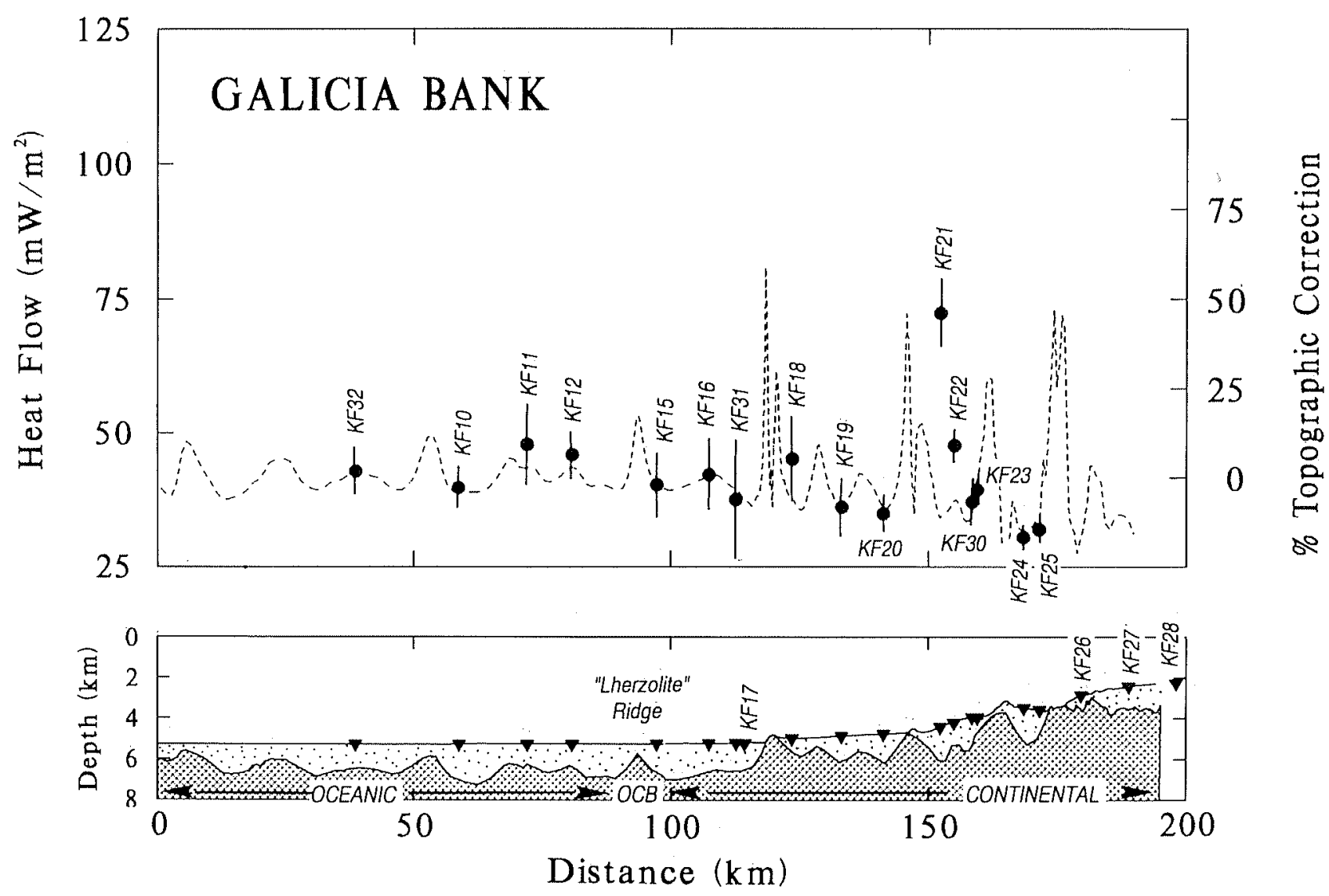

Fig. 11. Station locations, corrected heat flow $( \pm 1 \sigma)$ and topographic correction factor along the GP-101 reflection profile. Corrections are calculated for simplified boundiries separating low-conductivity postrift sediments from high-conductivity basement as identified in the simplified reflection section. Note decrease across margin from ocean to continent.

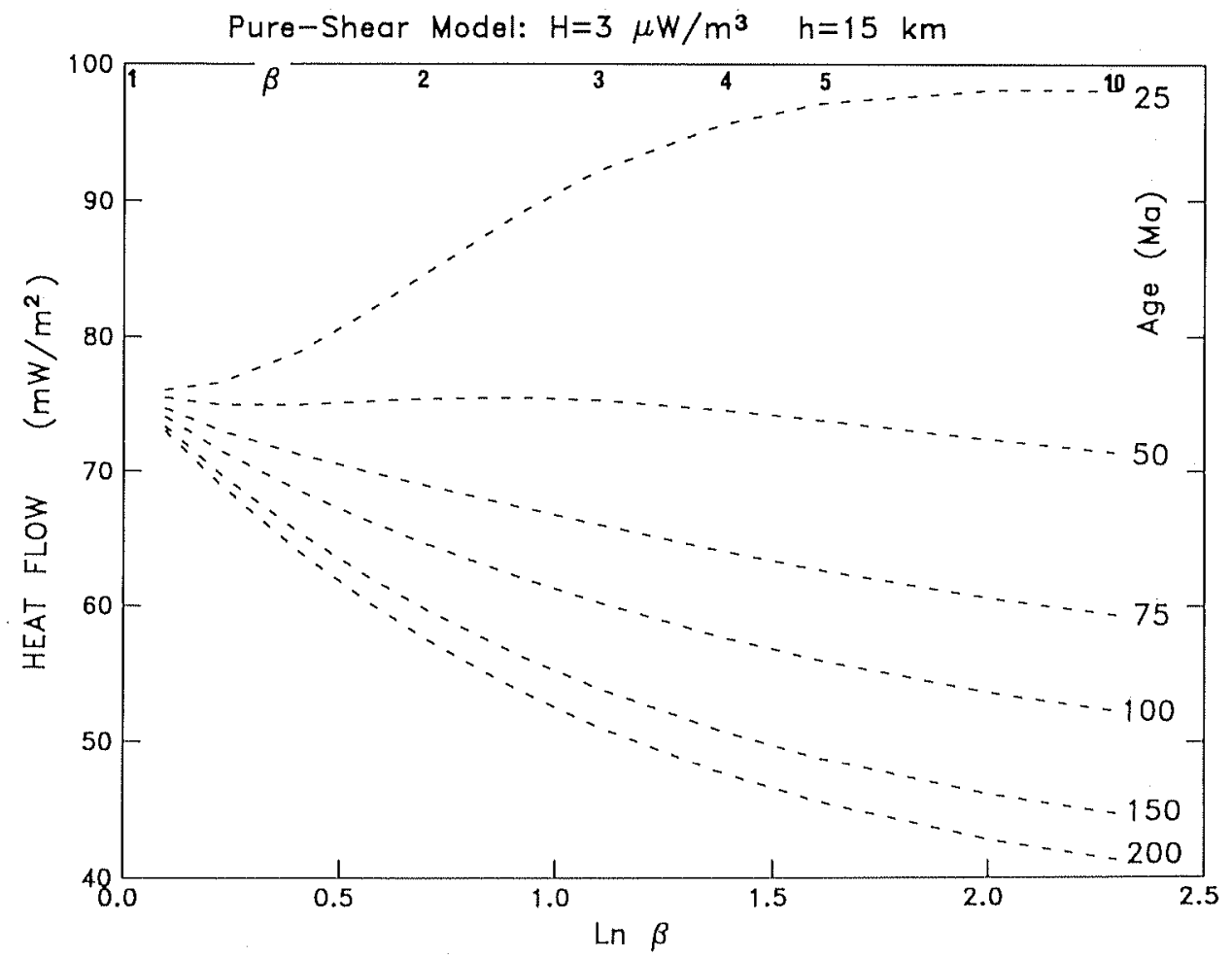

Fig. 12. Variations in heat llow with stretching factor $(\beta)$ for the pureshear model [McKenzie, 1978] including the effects of radiogenic heating [Voorhoeve and Houseman, 1988]. Separatc curves are for separate lithospheric ages as indicated in millions of years; assumed values of radiogenic heat production $(H)$ and thickness $(h)$ are 3 $\mu \mathrm{W} / \mathrm{m}^{3}$ and $15 \mathrm{~km}$, respectively. 


\section{GOBAN SPUR}

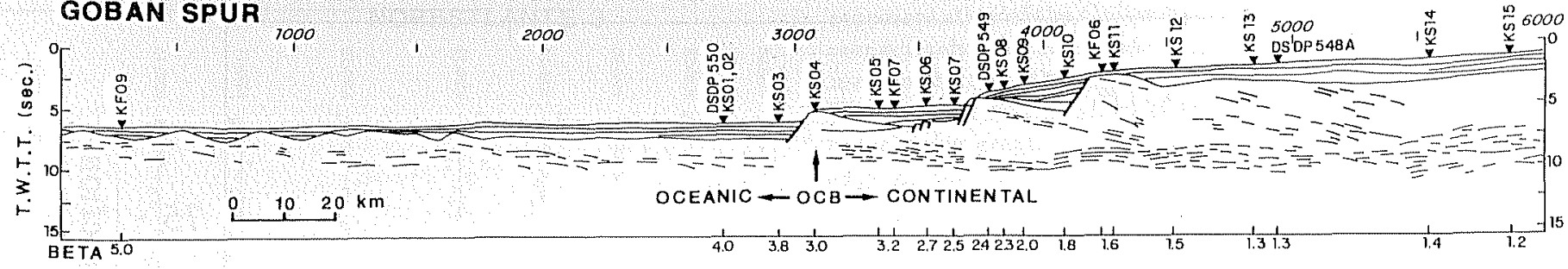

\section{GALICIA BANK}

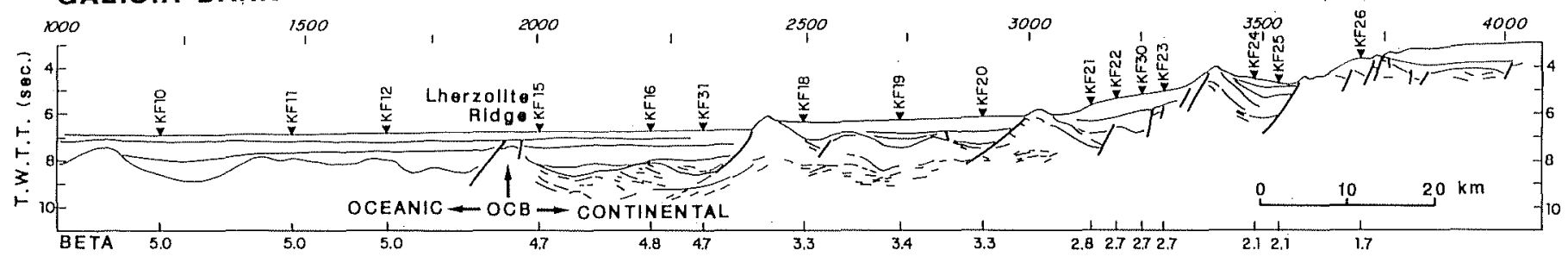

Fig. 13. Multichannel profiles WAM (Goban Spur) and GP101 (Galicia Bank) with locations of heat flow stations and calculated values of stretching parameter $\beta$. Reflections from tilted fault blocks, postrift sediments, and crustal reflectors and interpreted locations of ocean-continent boundary are identified in simplified line drawings.

stretching factors [e.g., LePichon et al., 1983; Chenet et al., 1983].

For Galicia Bank, the GP-101 profile (Figure 13b) does not exhibit a highly reflective lower crust terminating at the Moho as seen on the WAM profile; nor is there an isolated, identifiable Moho reflection. Thus we, must use an indirect technique to calculate $\beta$. We have chosen to use the geometry of tilted fault blocks, which in this case are not seriously eroded (Figure 13b), following the relationship $Z=Z_{t}(1-1 / \beta)$, as described by Le Pichon and Sibuet [1981], where $Z$ is the sediment-corrected basement depth of the tilted blocks, $\beta$ is the distance between two consecutive blocks divided by the width of the block, and $Z_{t}$ is the oceanic depth for the appropriate crustal age $t$. In Figure 14, a value for $Z_{t}$ of $7.5 \mathrm{~km}$ is estimated from observations across the Galacia margin ( $t=114 \mathrm{Ma}$ ) compared to a value of $6.4 \mathrm{~km}$ for Goban Spur ( $t=105 \mathrm{Ma}$ ). The larger slope chosen for Galicia Bank will influence our calculation for $\beta>2.5$ (or $Z>4 \mathrm{~km}$ ), to yield a smaller estimate for $\beta$ than it would for the same subsidence, $Z$, at Goban Spur.

We also note in Figure 14 that values of $\beta$ calculated from the tilting of the fault blocks do not follow a linear trend for the lower part of the margin, beginning approximately at the appearance of the intracrustal S reflector (shot point 3000 on Figure 13b). In addition, the average sediment-corrected basement depth for the oceanic crust west of Galicia Bank $(6.30 \pm 0.02 \mathrm{~km})$ is $1 \mathrm{~km}$ greater than for oceanic crust west of Goban Spur $(5.30 \pm 0.16 \mathrm{~km})$. These values are split by theoretical predictions of $5.8-5.9 \mathrm{~km}$ for oceanic crust of ages between 105 and $115 \mathrm{Ma}$ [Parsons and Sclater, 1977]. The cause of these depth variations are unexplained but could cause us to overestimate $\beta$ values over the outer margin of Galicia Bank relative to those for Goban Spur. The results of seismic refraction measurements across both Goban Spur and Galicia Bank will allow us eventually to compare techniques in refining the calculation of $\beta$; although we doubt that minor differences will alter the conclusions of this paper.

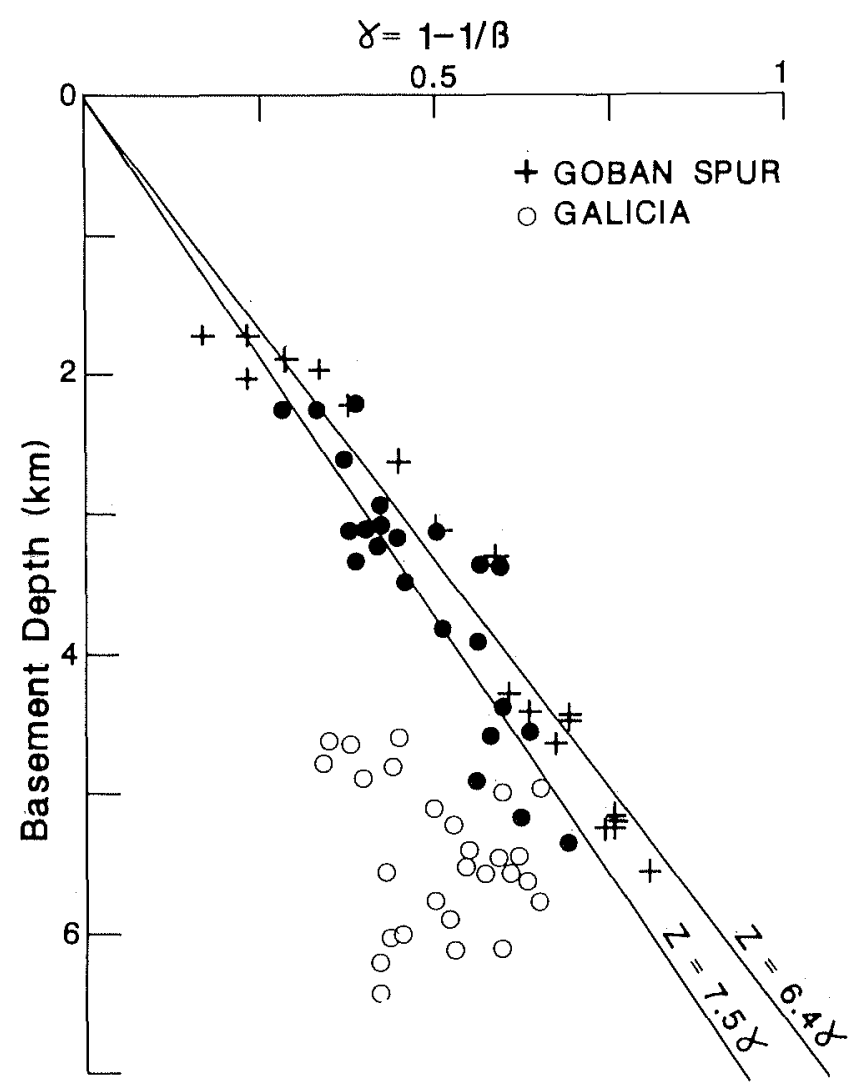

Fig. 14. Values of superficial extension as a function of sedimentcorrected basement depth across the Galicia Bank continental margin (solid and open circles from Sibuet [1987]) compared to direct measurement of $\beta$ versus subsidence across Goban Spur (crosses) derived from variations in crustal thickness along the WAM profile (Figure 13a). For Galicia Bank, solid symbols correspond to the upper part of the margin (shot points 3000 4000 in Figure 13b), while open symbols correspond to the lower part (shot points 2000-3000) above the location of the midcrustal $S$ reflector. 
In Figure 15, a comparison of heat flow observations across the two margins, including mean continental values from the shaded areas shown in Figure 1, to theoretical values from the pure-shear model for a variety of assumed initial contributions from radiogenic heating $(H h)$ shows that:

1. For Goban Spur, the majority of observations remain relatively constant for values of $\beta$ larger than 1.5 . This
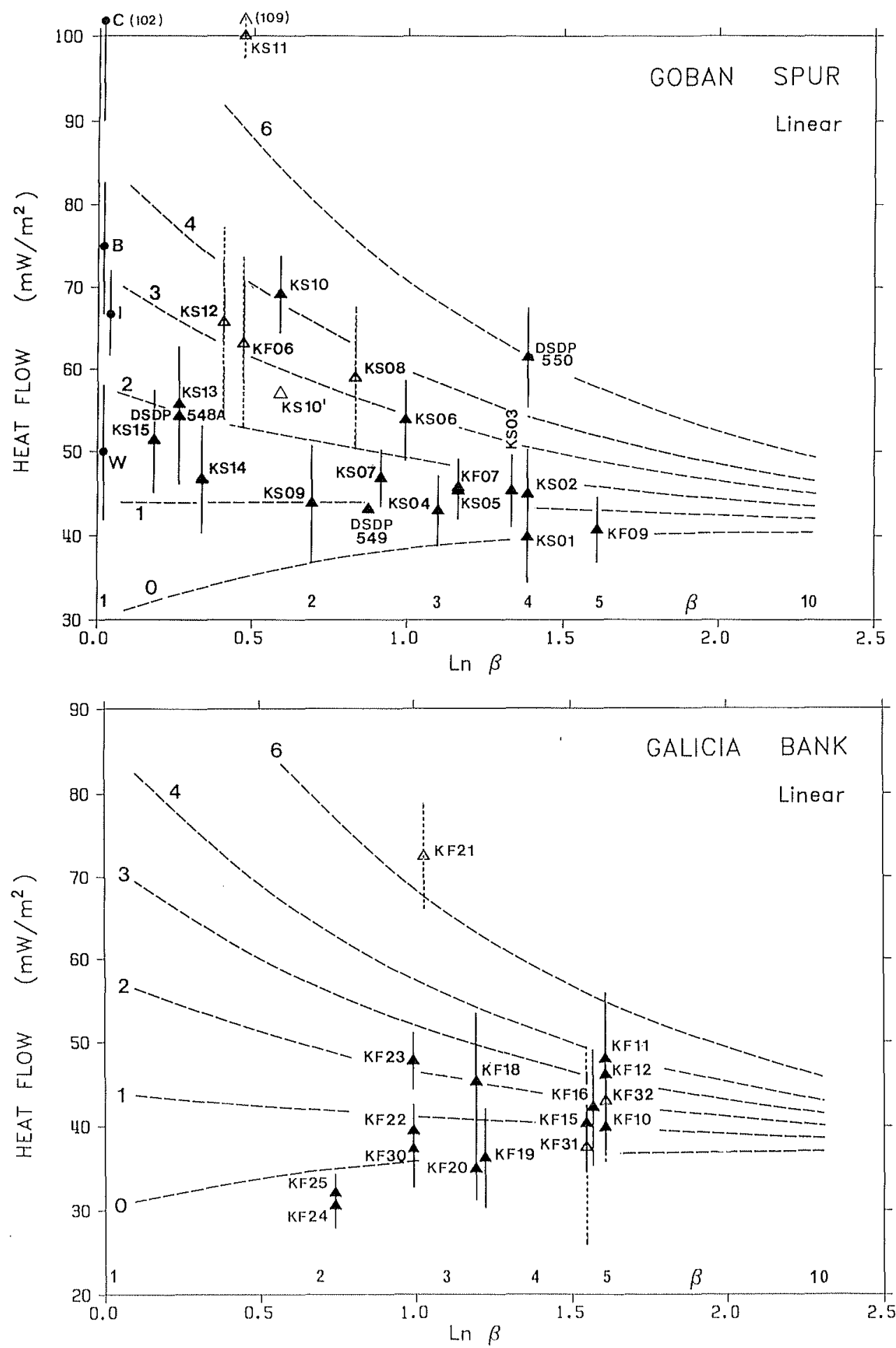

Fig. 15. Values of corrected heat flow $( \pm 1 \sigma)$ across Goban Spur and Galicia Bank as functions of stretching parameter $\beta$, compared to pure-shear models with linear relationship of radiogenic contribution to $\beta$. Open symbols and dotted error bars indicate values with significant nonlinearities in temperatures. Value for KS10 (Goban Spur) uses gradient, from deepest two temperatures only. Lithospheric ages for Goban Spur and Galicia Bank are 105 and $114 \mathrm{Ma}$, respectively. Values of radiogenic heat production $(H)$ for separate curves are given in $\mu \mathrm{W} / \mathrm{m}^{3}$; thickness of radiogenic layer $(h)$ is $15 \mathrm{~km}$ in all cases. Other parameters in the model are the same as used in Figure 12 except the in situ asthenospheric temperature $\left(T_{a}\right)$, which is $1200^{\circ} \mathrm{C}$. 
would suggest only a small contribution from racliogenic heat production, with initial values between $I$ and $2 \mu \mathrm{W} / \mathrm{m}^{3}$ that would produce continental heat flow between 45 and $60 \mathrm{~mW} / \mathrm{m}^{2}$ similar to those observed in Wales $(H=1.29 \pm$ $0.66 \mu \mathrm{W} / \mathrm{m}^{3}, h=15 \mathrm{~km}$ ) [Richardson and Oxburgh, 1978]. These fall below the observed mean values of heat flow from Brittany and Ireland of $70-80 \mathrm{~mW} / \mathrm{m}^{2}$, as well as the high mean radiogenic heat production $\left(H=3.2 \pm 1.2 \mu \mathrm{W} / \mathrm{m}^{3}\right.$, $h=15.6 \pm 0.6 \mathrm{~km}$ ) from Brittany [Jolivet et al., 1989]. There are some higher heat flow observations which fit models with initial radiogenic heating of $3-4 \mu \mathrm{W} / \mathrm{m}^{3}$, but these come from shallow penetrations which may have been affected by BTVs, as discussed in the preceding section. The close agreement of the deeper, borehole measurements from DSDP sites $548 \mathrm{~A}$ and 549 with low surface measurements gives added confidence that these lower values have not been significantly perturbed by environmental factors.

2. For Galicia Bank, apart from the one sporadically high value at N3KF21, the previously noted decrease in heat flow across the margin from ocean to continent can
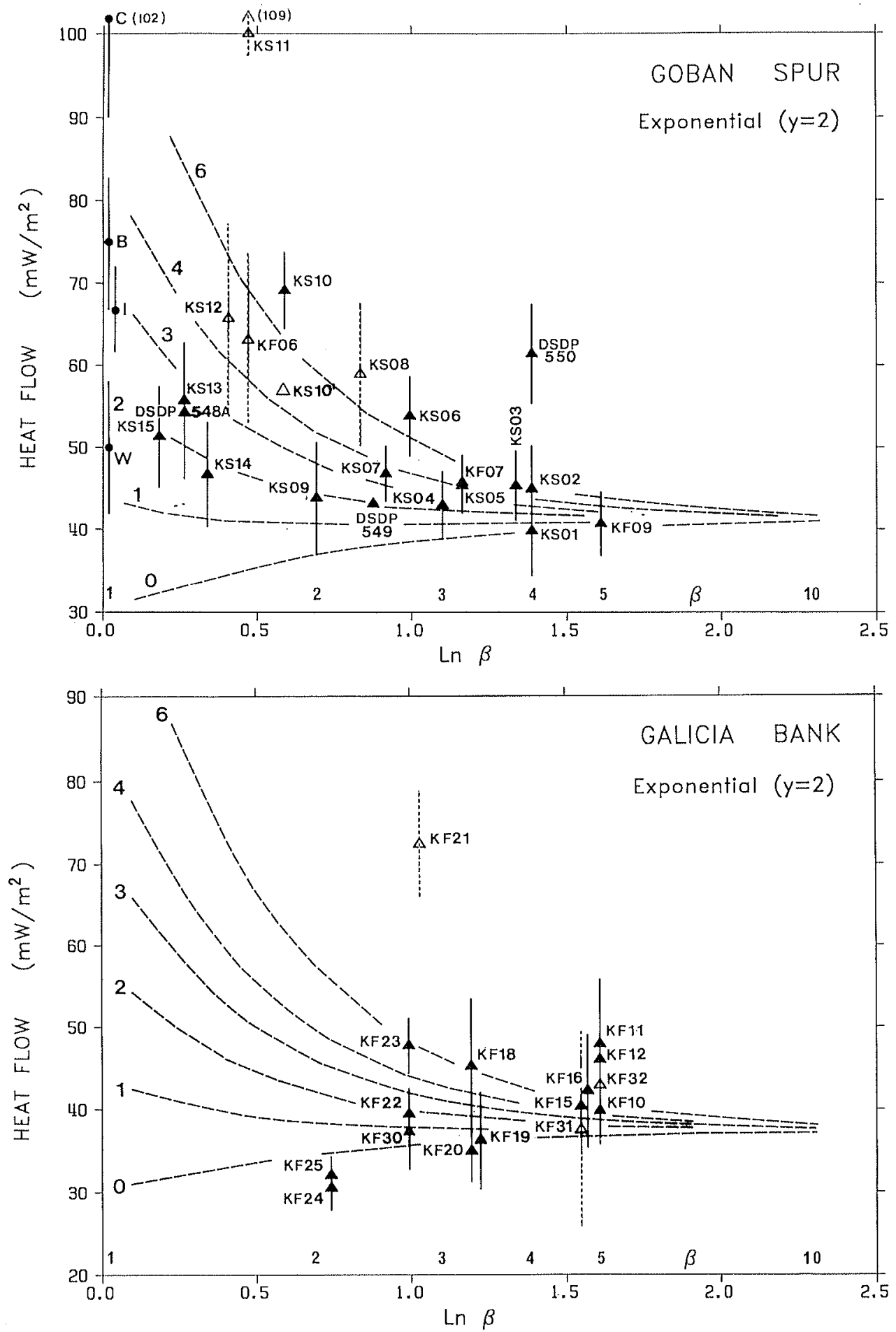

Fig. 16. Same as for Figure 15 except models use thermal contribution from radiogenic heating which decreases as $\beta^{-2}$. 
only be matched by models with essentially zero radiogenic contribution.

Values of radiogenic heat production have not been reported for basement samples from DSDP cores or dredge hauls across Goban Spur. However, low values are compatible with the placement of the main Hercynian metamorphic belt to the south of our transect, as indicated by Lefort et al. [1980].

Alternatively, if high values of radiogenic heat production more typical of rocks from Ireland, SW Cornwall, and Brittany are considered, the constant level of heat flow to relatively small values of $\beta$ across Goban Spur requires that radiogenic heat production decreases more rapidly than the thickness of the crust as a whole. This can be most simply modeled using a reduction in radiogenic heating as $\beta^{-y}$ where $y>1$. Qualitatively, this is what we would expect for a lower plate, simple shear model. More precise calculations [Voorhoeve and Houseman, 1988; Issler et al., 1989] would require further knowledge of the geometry of the detachment fault and assumption of how the rate of crustal radiogenic heat production decreases with depth.

Figure 16 compares observations to a model with $y=2$. In this case, most of the low heat flow measurements can be fit by an unstretched radiogenic contribution of $2-3$ $\mu \mathrm{W} / \mathrm{m}^{3}$, while the higher measurements fit models with 4$6 \mu \mathrm{W} / \mathrm{m}^{3}$. If the higher measurements are representative of the tiue heat flow at depth, and not artifacts of particular BTVs, they may indicate real spatial variations in radiogenic heat production across the margin. Similar variations over distances of $50-100 \mathrm{~km}$ are clearly observed in the land heat flow data (see Figure 1), due primarily to the distribution of outcropping Hercynian granite batholiths. There is no reason to believe that similar heterogeneous geological continental structures do not also extend seaward across the margin [Sibuet et al., 1990]. If, however, the high measurements result from BTVs, we could improve our fit to the low heat flow at small $\beta$ by increasing $y$ to values of $3-4$. The same type of model could also explain previous data from the Biscay margin [Foucher and Sibuet, 1980], where heat flow values scatter between 36 and $47 \mathrm{~mW} / \mathrm{m}^{2}$ without significant increase, for $\beta$ between 4 and 1.3 .

For Galicia Bank (Figure 16), a similar model does not improve the fit, and one must still conclude that its continental crust has negligible radiogenic material. Although continental heat flow measurements are lacking within the Paleozoic section of northwestern Spain, the similarity in mean continental heat flow between most other Paleozoic sections (Wales excepted) suggests that this is not due to differences in the unstretched continental crust. Instead, it may be related to the Late Jurassic rifting episode that separated the outer bank from the continental mainland to create the Interior basin. We estimate a $\beta$ value for this incipient rifting between 1.2 and 1.4 (Figure 14) from the $1-2 \mathrm{~km}$ of minimum subsidence for the Galicia Bank region (Figure 5). An attenuation of radiogenic heat production, in an exponential manner as modeled for Goban Spur, would predict a reduction of $30-50 \%$ in radiogenic heating for this value of $\beta$. Subsequent rifting during the Early Cretaceous would have commenced with a continental crust that might have already lost a significant fraction of its radiogenic material, in qualitative agreement with our observations. Confirmation of this suggestion must, however, await direct measurement of crustal radiogenic heat production.

\section{Conclusions}

The results of this study indicate the following:

1. The variation in heat flow across Goban Spur agrees with either pure-shear or lower plate, simple shear modes of rifting; there is no evidence for an upper plate origin. Given the consistency with changes in crustal structure shown by multichannel profiles, we prefer the pure-shear model. However, in that case the heat flow requires that the uppermost crust has relatively low concentrations of radiogenic material. To verify this, we need direct measurement of radiogenic heat production rates from borehole samples along the transect within the thinned continental crust.

2. The heat flow variation across the Galicia Bank is atypical, decreasing instead of increasing as the continental crust thickens. This result requires that its continental crust be totally depleted in radiogenic material, either from its beginning or as caused by a previous period of asymmetric rifting as a lower plate margin. There is no evidence which requires an upper plate origin for Galicia Bank. Unfortunately, microfaunal estimates of paleodepths at ODP sites 638,639 , and 641 [Moullade et al., 1988] are too imprecise in these bathyal depths to add further constraints. Without such additional data, the existence of a previous rifting event which reduced the radiogenic upper crust is unproven.

We have also shown that significant nonlinearities in temperature gradients complicate our ability to measure the basement heat flow of both margins for low values of $\beta$. These perturbations are primarily caused by variations in bottom water temperature, most likely produced by deeply penetrating mesoscale eddies. These eddies can cause BTVs at depths where significant vertical gradients in the water temperature exist and are particularly evident across Goban Spur where they interact with the warm water outflow from the Mediterranean. Increased resolution will require subbottom penetrations of $8-10 \mathrm{~m}$ or geographically coincident observations separated by a period of approximately 1 month.

Two heat flow stations have very high values which cannot be explained by BTVs: DSDP 550 on oceanic crust immediately west of the Goban Spur margin and station KF 21 on transitional crust west of Galicia Bank. The DSDP value does not agree with measurements from shallow penetrations in close proximity, but the reason for this large discrepancy is not obvious in the DSDP data. The high value at KF21 may indicate the presence of local erosional processes, of hydrothermal circulation, or of an abrupt local variation in crustal heat production. Disturbance of the lower two thermistors make this station too shallow to be conclusive.

We also show that there is a significant difference in the mean sediment-corrected basement depth of oceanic crust in the two regions. Values west of Galicia Bank are $1 \mathrm{~km}$ greater than values west of Goban Spur. The greater depths adjacent to Galicia Bank appear to be regional in extent rather than related to the formation of Galicia Bank per se, as sediment-corrected basement depths of between 6 and $7 \mathrm{~km}$ exist on oceanic crust south of Galicia Bank in the Iberia and Tagus abyssal plains [Whitmarsh et al., 1990; Mauffret et al., 1989]. The cause of these larger depths may partly be explained by crustal isostatic imbalances between 
regions. The free-air gravity anomaly map of Lalaut et al. [1981] shows negative anomalies of -30 to $-50 \mathrm{mGal}$ in the Iberia and Tagus abyssal plains off western Galicia Bank and Portugal, compared to positive values of 10 to $20 \mathrm{mGal}$ west of Goban Spur. However, to create an extra $1 \mathrm{~km}$ subsidence requires an original continental crust that is approximately $15 \%$ thicker (e.g., 35 versus $30 \mathrm{~km}$ ) or less dense (2.8 versus $\left.2.9 \mathrm{Mg} / \mathrm{m}^{3}\right)$. If totally uncompensated by thinner or more dense oceanic crust, this would create a free air anomaly of $-100 \mathrm{mGal}$, or nearly twice that which is observed. Changes in oceanic crustal structure between basins could help to reduce the expected anomaly.

We finally note that low values of heat flow on oceanic crust, particularly those west of Goban Spur, are consistent with an in situ asthenospheric temperature of roughly $1200^{\circ} \mathrm{C}$. This is roughly $100^{\circ} \mathrm{C}$ lower than suggested values of $1280^{\circ} \mathrm{C}$ for the creation of standard oceanic crust [Foucher et al., 1982; McKenzie and Bickle, 1988]. A low asthenospheric temperature is consistent with the nonvolcanic nature of this margin but would imply, using the simplest petrologic model, the generation of unusually thin (about $2 \mathrm{~km}$ thick) oceanic crust. On the other hand, above normal basement depths and near zero free air anomalies west of Goban Spur suggest that this is probably not the case. Unusual crustal structure may, however, be indicated by the greater basement depths west and south of Galicia Bank as discussed above, but this suggestion requires further justification from refraction profiles.

Acknowledgements. We would like to thank the officers and crew of the N/O Le Suroit and the N/O Jean Charcot, and the technical support personnel (C. Toularastel, J.-P. Quéré, and J.P. Le Formal) from the Département de Géosciences Marines (IFREMER, Centre de Brest), who helped take the heat How measurements at sea. K.E.L. was supported while at IFREMER by a burse from the French government (Ministère des Affaires Étrangères) and while writing this paper at Dalhousie University by N.S.E.R.C. grant OGP0008459. C. Jaupart kindly supplied the computer code for making the two-dimensional topographic corrections, and S. Levesque supplied the code for calculating the effects of bottom water temperature variations. H. Pollack supplied a listing of continental heat flow values in France, Spain, and Great Britain. J.-P. Mazé helped draft the figures. G. Hammer helped prepare the text.

\section{REFERENCES}

Albert-Beltran, J.F., Heat flow and temperature gradient data from Spain, in Terrestrial Heat Flou in Europe, edited by V. Cermak and L. Rybach, pp. 261-266, Springer-Verlag, New York, 1979.

Avedik, F., A.L. Camus, A. Ginzburg, L. Montadert, D.G. Roberts, and R.B. Whitmarsh, A seismic refraction and reflection study of the continent-ocean transition beneath the North Biscay margin, Philos. Trans. R. Soc. London, Ser. A, $305,5-25,1982$.

Bloomer, J.R., S.W. Richardson, and E.R. Oxburgh, Heat flow in Britain: an assessment of the values and their reliability, in Terrestrial Heat Flow in Europe, edited by V. Cermak and L. Rybach, pp. 293-300, Springer-Verlag, New York, 1979.

Boillot, G., S. Grimaud, A. Mauffret, D. Mougenot, J. Kornprobst, J. Mergoil-Daniel, and G. Torrent, Oceancontinent transition off the Tberian margin: a serpentinite diapir west of Galicia Bank, Earth Planet. Sci. Lett., 48, $23-34,1980$

Boillot, G., M. Comas, J. Girardeau, J. Komprobst, J.-P. Loreau, J. Malod, D. Mougenot, and M. Moullade, Fonds sousmarins basaltiques et ultramafiques au pied d'une marge stable. Résultats préliminaires de la campagne Galinaute (plongées du submersible Nautile à l'Ouest de l'Espagne), C. R. Acad. S'ci.,
Ser. 2, 303, 1719-1724, 1986.

Boillot, G., et al, Tectonic denudation of the upper mantle along passive margins: a model based on drilling results (ODP Leg 103, western Galicia margin, Spain), Tectonophysics, 132, $335-342,1987$.

Boillot, G., J. Girardeau, and J. Komprobst, Rifting of the Galicia margin: crustal thinning and emplacement of mantle rocks on the sealloor, Proc, Ocean Drill. Program, Sci. Results, 109, 711-756, 1988.

Brock, A., Heat flow measurements in Treland, Tectonophysics, 164, 231-236, 1989.

Buck, W.R., F. Martinez, M.S. Steckler, and J.R. Cochran, Thermal consequences of lithospheric extension: Pure and simple, Tectonics, 7, 213-234, 1988.

Chenet, P.-Y., L. Montadert, H. Gairaud, and D. Roberts Extension ratio measurements on the Galicia, Portugal and northern Biscay continental margins: implications for evolutionary models of passive continental margins, in Studies in Continental Margin Geology, edited by J.S. Watkins and C.L. Drake, AAPG Mem. 34, 703-715, 1983.

Erickson, A.J., W.E. Avera, and R. Byrne, Heat flow results, DSDP Leg 48, Initial. Rep. Deep Sea Drill. Prog., $48,277-$ 288,1979

Foucher, J.-P. and J.-C. Sibuet, Thermal regirne of the northern Bay of Biscay continental margin in the vicinity of the D.S.D.P. Sites 400-402, Philos. Trans. R. Soc. London, Ser. A, 294 $157-167,1980$.

Foucher, J.-P., X. Le Pichon, and J.-C. Sibuet, The oceancontinent transition in the uniform lithospheric stretching model: role of partial melting in the mantle, Philos. Trans. R. Soc. London, Ser, A, 305,27-43, 1982.

Foucher, J.-P., P.-Y. Chenet, L. Montadert and J.-M. Roux, Geothermal measurements during Deep Sea Drilling Project Leg 80, Initial Rep. Deep Sea Drill. Prog., 80, 423-436, 1985.

Fuglister, F.C., Ocean Atlas of Temperature and Salinity Profiles and Data from the International Geophysical Year of 19571958, Woods Hole Oceanogr. Inst. Atlas Ser., vol. 1, 209 pp., Woods Hole, Mass., 1960.

Goldberg, D.S., The Physical Properties of Deep Ocean Sediments from the Northern Atlantic: A Comparison of InSitu and Laboratory Methods, M.Sc. thesis, Mass. Inst. of Technol., Cambridge, 1981.

Gould, W.J., The Northeast Atlantic Ocean, in Eddies in Marine Science, edited by A.R. Robinson, pp. 145-157, SpringerVerlag, New York, 1983.

Guennoc, P., H. Jonquet, and J.-C. Sibuet, Carte magnétique de I'Atlantique nord-est, anomalies du champ total; scale $1: 2,400,000$, Inst. Fr. de Rech. pour l'Exploit. de la Mer, Paris, 1978. (Available from BRGM, Serv. Promotion et Vente, Orléans, France).

Hutchison, I., The effects of sedimentation and compaction on oceanic heat flow, Geophys. J. R. Astron. Soc., 82, 439-460, 1985.

Hyndman, R.D., M.G. Langseth, and R.P. Von Herzen, Deep Sea Drilling Project geothermal measurements: a review, Rev. Geophys., 25, 1563-1582, 1987.

Issler, D., H. McQueen, and C. Beaumont, Thermal and isostatic consequences of simple shear extension of the continental lithosphere, Earth Planet. Sci. Lett, 91, 341-358, 1989.

Jolivet, J., G. Bienfait, J,-L. Vigneresse, and M. Cuney, Heat flow and heat production in Brittany (western France), Tectonophysics, 159, 61-72, 1989.

Keen, C.E., and B. de Voogd, The continent-ocean boundary at the rifted margin off eastern Canada: New results from deep seismic reflection studies, Tectonics, 7, 107-124, 1988

Keen, C.E., C. Peddy, B. de Voogd, D. Matthews, Conjugate margins of Canada and Europe: results from deep reflection profiling, Geology, 17, 173-176, 1989.

Lalaut, P., J.-C. Sibuet, and C. Williams, Présentation d'une carte gravimétrique de l'Atlantique nort-est, $C . R$. A cad. Sci., Ser. 2, 292, 597-600, 1981.

Lallemand, S., J.-P. Mazé, S. Monti, and J.-C. Sibuet, Carte bathymétrique de l'Atlantique nord-est, scale 1:2,400,000, Ifremer, Paris, 1985. (Available from BRGM, Serv. Promotion et Vente, Orléans, France). 
Lefort, J.-P., J.-J. Peucat, J. Deunf, and A. Le Herisse, The Goban Spur Paleozoic basement, Initial Rep. Deep Sea Drill. Prog., 80, 677-679, 1980.

Le Groupe Tourbillon, The Tourbillon experiment: a study of a mesoscale eddy in the eastern North Atlantic, Deep Sea Res., $30,475-511,1983$

Le Pichon, X., and F. Barbier, Passive margin formation by lowangle faulting within the upper crust: The northern Bay of Biscay margin, Tectonics, 6, 133-150, 1987.

Le Pichon, X., and J.-C. Sibuet, Comments on the evolution of the north-east Atlantic, Nature, 233, 257-258, 1971.

Le Pichon, X., and J.-C. Sibuet, Passive margins: A model of formation, J. Geophys. Res., 86, 3708-3720, 1981.

Le Pichon, X., J. Angelier, and J.-C. Sibuet, Subsidence and stretching, in Studies in Continental Margin Geology, edited by J.S. Watkins and C.L. Clarke, AAPG Mem. 29, 731-741, 1983.

Louden, K.E., and J.A. Wright, Marine heat flow data: a new compilation of observations and brief review of its analysis, in Handbook of Seafloor Heat Flow, edited by J.A. Wright and K.E. Louden, pp. 3-70, CRC Press, Boca Raton, Fla., 1989.

Lucazeau, F., and S. Le Douaran, The blanketing effect of sediments in basins formed by extension: a numerical model, application to the Gulf of Lion and Viking graben, Earth Planet. Sci. Lett., 74, 92-102, 1985.

Lucazeau, F., and G. Vasseur, Heat flow density data from France and surrounding margins, Tectonophysics, 164, 251$258,1989$.

Masson, D.G., and P.R. Miles, Mesozoic seafloor spreading between Iberia, Europe and North America, Mar. Geol., 56, $279-287,1984$.

Masson, D.G., L. Montadert, and R.A. Scrutton, Regional Geology of the Goban Spur continental margin, Initial Rep. Deep Sea Drill. Prog., 80, 1115-1140, 1985.

Mauffret, A. and L. Montadert, Rift tectonics on the passive continental margin off Galicia (Spain), Mar. Pet. Geol., 4, $49-69,1987$.

Mauffret, A., D. Mougenot, P.R. Miles, and J.A. Malod, Cenozoic deformation and Mesozoic abandoned spreading centre in the Tagus Abyssal Plain (west of Portugal): results of a multichannel seismic survey, Can. J. Earth Sci, 26, 11011123, 1989.

Maury, R.C., H. Gellon, H. Bougault, J.-L. Joron, M. Bohn, and P.-C. de Graciansky, Oceanic tholeiites from Leg 80 sites (Celtic Sea passive margin, Northeastern Atlantic): geochenuistry and mineralogy, Initial Rep. Deep Sea Drill. Prog., 80, 939-946, 1985.

McKenzie, D., Some remarks on the development of sedimentary basins, Earth Planet. Sci. Lett., 40, 25-32, 1978.

McKenzie, D., and M.J. Bickle, The volume and composition of melt generated by extension of the lithosphere, J. Petrol., 29, 625-679, 1988.

Montadert, L., D.G. Roberts, O. de Charpel, and P. Guennoc, Rifting and subsidence of the northern continental margin of the Bay of Biscay, Initial Rep. Deep Sea Drill. Prog., 48, 1025-1060, 1979a.

Montadert, L., O. de Charpal, D. Roberts, P. Guennoc, and J.-C. Sibuet, Northeast Atlantic passive margins: rifting and subsidence processes, in Deep Drilling Results in the Altantic Ocean: Continental Margins and Paleoenvironment, Maurice Ewing Ser., vol. 3, edited by M. Talwani, W.W. Hay, and W.B.F. Ryan, pp. 164-186, AGU, 1979h.

Moullade, M., M.-F. Brunet, and G. Boillot, Subsidence and deepening of the Galicia margin: the paleocnvironmental control, Proc, Ocean Drill. Program Sci. Results, 103, 733740,1988

Murillas, J., D. Mougenot, G. Boillot, M.C. Comas, E. Banda, and $A$. Mauffret, Structure and evolution of the Galicia Interior basin (Atlantic western Iberian continental margin), Tectonophysics, 134, 297-319, 1990.

Olivet, J.-L., J. Bonnin, P. Beuzart, and J.-M. Auzende, Cinćmatique de l'Atlantique Norl et Central, 108 pp., Centre National pour l'Exploitation des Océans, Paris, 1984.

Parsons, B., and J.G. Sclater, An analysis of the variation of ocean floor bathymetry and heat flow with age, J. Geophys. Res., 82, 803-827, 1977.
Peddy, C., B. Pinet, D. Masson, R. Scrutton, J.-C. Sibuet, M.R. Warner, J.-P. Lefort, and I.J. Shroeder, Crustal structure of the Goban Spur continental margin, Northeast Atlantic, from deep seismic reflection profiling, J. Geol. Soc. London, 146, 427-437, 1989.

Pinet, C., and C. Jaupart, The vertical distribution of radiogenic heat production in the Precambrian crust of Norway and Sweden: Geothermal implications, Geophys. Res. Lett., 14, 260-263, 1987.

Ratcliffe, E.H., The thermal conductivities of ocean sediments, J. Geophys. Res., 65, 1535-1541, 1960.

Reid, J.L., On the middepth circulation and salinity field in the North Atlantic Ocean, J. Geophys. Res., 83, 5063-5067, 1978.

Richardson, S.W., and E.R. Oxburgh, Heat flow, radiogenic heat production and crustal temperatures in England and Wales, $J$. Geol. Soc. London, 135, 323-337, 1978.

Roberts, D.G., D.G. Masson, and L. Montadert, Continental margin from the Porcupine Seabight to the Armorican marginal basin, in Petroleum Geology of the Continental Shelf of Northwest Europe, edited by L.V. Illing and G.D. Hobson, pp. 455-473, Institute of Petroleum, London, 1981.

Royden, L., and C.E. Keen, Rifting processes and thermal evolution of the continental maritn of eastern Canada determined from subsidence curves, Earth Planet. Sci. Lett., $51,343-361,1980$.

Sibuet, J.-C., Contribution à l'étude des mécanismes de formation des marges continentales passives, Thèse de doctorat d'état, 351 pp., Univ. de Bretagne Occidentale, Brest, France, 1987.

Sibuet, J.-C., and B. Collette, Triple junctions of Bay of Biscay and North Atlantic: new constraints on the kinematic evolution, Geology, in press, 1991.

Sibuet, J.-C., and X. Le Pichon, Structure gravimétrique du Golfe de Gascogne et le fossé marginal nord-espagnol, in Histoire Structurale du Golfe de Gascogne, vol. VI-9, edited by J. Debyser, X. Le Pichon, and L. Montadert, pp. 1-18, Technip, Paris, 1971.

Sibuet, J.-C., B. Mathis, L. Pastouret, J.-M. Auzende, J.P. Foucher, P.M. Hunter, P. Guennoc, P.-C. de Graciansky, L. Montadert, and D.G. Masson, Morphology and basement, structure of the Goban Spur continental margin (northeastern Atlantic) and the role of the Pyrenean orogeny, Initial Rep. Deep Sea Drill. Prog., 80, 1153-1165, 1985.

Sibuet, J.-C., J.-P. Mazé, P. Amortila, and X. Le Pichon, Physiography and structure of the western Iberian continental margin off Galicia from Sea-Beam and seismic data, Proc. Ocean Drill. Prog. Initial Rep., 103, 77-97, 1987.

Sibuet, J.-C., J. Dyment, C. Bois, B. Pinet, and H. Ondréas, Crustal structure of the Celtic Sea and western approches from gravity data and deep seismic profiles: Constraints on the formation of continental basins, J. Geophys. Res., 95, 10,999$11,020,1990$.

Srivastava, S.P., and C.R. Tapscott, Plate kinematics of the North Atlantic, in The Geology of North America, Vol. $M$, The Western North Atlantic Region, edited by P.R. Vogt and B.E. Tucholke, pp. 379-404, Geological Society of America, Boulder, Colo., 1986.

Srivastava, S.P., J. Verhoef, and R. Macnab, Results from a detailed aeromagneitc survey across the northeast Newfoundland margin, part 2, Early opening of the North Atlantic between the British Isles and Newfoundland, Mar. Pet. Geol., 5, 324-337, 1988.

Srivastava, S.P., H. Schouten, W.R. Roest, K.D. Klitgord, L.C. Kovacs, J. Verhoef, and R. Macnab, Iberian plate kinematics: a jumping plate boundary between Eurasia and Africa, Nature, $394,756-759,1990$.

Tankard, A.J., and H.J. Welsink, Extensional tectonics, structural styles and stratigraphy of the Mesozoic Grand Banks of Newfoundland, in Triassic-Jurassic Rifting and the Opening of the Atlantic Ocean, edited by W. Manspeizer, pp. 129-165, Elsevier Science, New York, 1988.

Verhoef, J., B.J. Gollette, P.R. Miles, R.C. Searle, J.-C. Sibuet, and C.A. Williams, Magnetic anomalies in the northeast Atlantic Ocean $\left(35^{\circ}-50^{\circ} \mathrm{N}\right)$, Mar. Geophys. Res., 8, 1-25, 1986.

Von Herzen, R.P., and A.E. Maxwell, The measurement of 
thermal conductivity of deep-sea sediments by a needle probe method, J. Geophys. Res., 64, 1557-1563, 1959.

Voorhoeve, H., and G. Houseman, The thermal evolution of lithosphere extending on a low-angle detachment, zone, Basin Res., 1, 1-9, 1988 .

Wang, K. and A.E. Beck, Heat flow measurement in lacustrine or oceanic sediments without recording bottom temperature variations, J. Geophys. Res., 92, 12,837-12,845, 1987.

Watremez, P., Flux de chaleur sur le massif armoricain et sur la marge continentale: essai de modèlisation de l'évolution thermique de la marge armoricaine, Thèse de 3ème cycle, 108 pp., Univ. de Bretagne Occidentale, Brest, France, 1980.

Wernicke, B., Uniform-sense normal simple shear of the continental lithosphere, Can. J. Earth Sci., 22, 108-125, 1985.

White, R.S., and C. Peddy, Discussion on crustal structure of the Goban Spur continental margin, Northeast Atlantic, from deep seismic reflection profiling, J. Geol. Soc. London, 147, $892-894,1990$.

Whitmarsh, R.B., P.R. Miles, and A. Mauffret, The oceancontinent boundary off the western continental margin of Iberia, Part I, Crustal structure at $40^{\circ} 30^{\prime} \mathrm{N}$, Geophys. J. Int., 103, 509-531, 1990.

Withjack, M.O., and W.R. Jamison, Deformation produced by oblique rifting, Tectonophysics, 126,99-124, 1986.

J.-P. Foucher and J.-C. Sibuet, IFREMER Centre de Brest, BP 70, 29263 Plouzané, France.

K.E. Louden, Department of Oceanography, Dalhousie University, Halifax, N.S., Canada B3H $4 \mathrm{~J} 1$.

(Received August 23, 1990; revised April 15, 1991 accepted June 4, 1991.) 